Article

\title{
The Challenge of American Folklore to the Humanities
}

\section{Simon J. Bronner}

School of Humanities, American Studies Program, The Pennsylvania State University, Middletown, PA 17057-4898, USA; sbronner@psu.edu

Received: 16 November 2017; Accepted: 16 February 2018; Published: 17 February 2018

\begin{abstract}
American Folklore consists of traditional knowledge and cultural practices engaged by inhabitants of the United States below Canada and above Mexico. American folklorists were influenced by nineteenth-century European humanistic scholarship that identified in traditional stories, songs, and speech among lower class peasants an artistic quality and claim to cultural nationalism. The United States, however, appeared to lack a peasant class and shared racial and ethnic stock associated in European perceptions with the production of folklore. The United States was a relatively young nation, compared to the ancient legacies of European kingdoms, and geographically the country's boundaries had moved since its inception to include an assortment of landscapes and peoples. Popularly, folklore in the United States is rhetorically used to refer to the veracity, and significance, of cultural knowledge in an uncertain, rapidly changing, individualistic society. It frequently refers to the expressions of this knowledge in story, song, speech, custom, and craft as meaningful for what it conveys and enacts about tradition in a future-oriented country. The essay provides the argument that folklore studies in the United States challenge Euro-centered humanistic legacies by emphasizing patterns associated with the American experience that are (1) democratic, (2) vernacular, and (3) incipient.
\end{abstract}

Keywords: folklore; folklorist; folkloristics; tradition; folktale; folksong; legend; joke; narrative; performance; practice theory; speech; ritual; rites of passage; internet; romantic nationalism; United States

\section{Introduction and Thesis}

In 1889, an international cast of folklorists including many from the United States descended upon London for the second International Folk-Lore Congress, thus institutionalizing the term describing the broad subject area of traditional knowledge and practices as "folklore" (Cocchiara 1971, pp. 77-94). The Americans faced a problem having their stories and songs accepted by their European colleagues as bona fide folklore worthy of aesthetic appreciation and scholarly analysis. The Americans did not boast a corpus of marvelous tales comparable to the Grimms' Märchen, poetic work measuring up to the grand epics and sagas celebrated in Scandinavia, or ancient myths in the classical tradition of the Greeks and Romans. To be sure, the young Republic had a diverse indigenous population who were credited with possessing myths and distinct belief systems. Yet American scholars working to justify a national identity struggled to show that a national culture composed of settlers from various Old World cultures was more than a diluted derivative of European immigration. By the end of the nineteenth century, that immigration reached massive proportions and appeared to transform the nation into a multi-lingual industrial, multi-racial, urban power. Nonetheless, the United States purportedly lacked a peasant class and homogeneous racial and ethnic stock associated in European perceptions with the production of folklore. The United States was a relatively young nation, compared to the ancient legacies of European kingdoms, and geographically the country's boundaries had moved since its inception to include an assortment of landscapes and peoples. 
If the Americans felt that their grassroots traditions had been belittled by the representatives of older cultural legacies of Europe and the civilizations further east of India and China, they also faced derision for their relative lack of fine arts. Europeans portrayed Americans as boorish and in need of European refinement with help from tastes for romantic literature, poetry, drama, and painting. The few institutions of higher learning and academies for advancement of the arts in North America paled in comparison to revered centers of learning such as Oxford, Cambridge, Paris, and Berlin. Indeed, American historian Daniel Boorstin has claimed that the United States began as a "modern culture which skipped the aristocratic phase." He wrote that "we have been without that deep bifurcation into high and low, which was the starting point of the national cultures of Western Europe" that set the tone for humanistic study (Boorstin 1956, p. 139).

Related to the idea of a class-based bifurcation of culture in Western Europe where ideas of folklore arose is a geography of urban centers featuring a vibrant intellectual life. "Almost every [European] country has had its Paris, its mecca of culture, where one could sit and be at the center of things," Boorstin (1956, p. 142) observed. In the United States, however, emerging scholars often searched for ideas in the vernacular experience of the everyman and woman on the move. They brought various traditions with them from the Old World and hybridized them with other sources to create a distinctive New World mix. If not lodged in ivory towers of renowned academies, the American scholar sought wisdom from the pragmatic experience of establishing a new nation, and attendant culture, characterized by regional and ethnic diversity at the grassroots. Writers looking for cultural revelations were forced to see practices in action across paths of migration from various ports of entry into broad inland regions. These writers, many of whom called themselves folklorists, provided challenges to the predominant elitist conceptualizations of the humanities, and the cultures of which they were a part.

In this essay, I trace the challenge of folklore studies to the Eurocentric concept humanities from the nineteenth century to the present. I argue that the significant patterns of American humanistic thought informed by folklore through the period of scholarly development from the nineteenth century to the twenty-first century have been:

1. Democratic. In keeping with the ideal of the United States as the first modern democracy, folklore-minded humanists established a cultural study that would be diverse, rather than seeking romantic nationalism, by representing the participation in national culture of various groups. That is not to say that Americans thought all these groups to be equal, and a task for many folklore-minded humanists was to recognize inequities by giving attention to groups facing domination or not given credit for their artistic, and therefore intellectual, capabilities. Folklorists showed artistry and tradition, and therefore claims to cultural integration, in the traditions of often marginalized groups. In the absence of a peasant class, the "American concept of folklore" that emerged by the mid-twentieth century featured an elastic, plural notion of group (Dundes 1966).

2. Vernacular. Because of attention by leading American folklorists to the separation, interaction, and hybridization of various groups in the production of practices viewed, and heard, as "tradition," folklore studies emphasized the "folk," or social aspect, in folklore. It was vernacular in the sense of often being localized, even if connected to apparently global, antecedent traditions. As studies evolved, the goal of identifying community with folkloric evidence extended to different situations as mobile social frames for the emergence of folklore (Bronner 1986, pp. 94-130). The separation of the humanities from social sciences therefore often came into question, since folklorists were concerned for social contexts as well as texts of culture. Those texts in a vernacular-centered perspective were analyzed for connections to everyday culture rather than a canon of work known by a learned or refined person.

3. Incipient. The European humanistic tradition was built upon reverence for ancient civilization and learning of the classics. To be sure, American higher education emphasized this tradition to the mid-twentieth century, but affecting scholarship was a movement of American studies reflecting a developing "modern" American culture. As the United States proclaimed itself a new 
nation that diverged from its sources in Europe and Africa, so did folklore presented as American reflect an incipient contemporaneous quality. It was in process. That is, it was developing and constantly being created anew, theory held, in the context of peculiar historical and geographic conditions. American folklorists certainly found evidence of intact transplanted customs but they specially pointed to traditions that emerged with American characteristics. Folklorists challenged the ancient foundation of the humanities by noting how American traditions observed as they were practiced reflected a forward-looking, inventive nation.

\section{The Social Grounding and Organization of American Folklore}

From the organization of the American Folklore Society in 1888, folklorists in the United States in answer to their European colleagues defined their purview along ethnic lines: surviving "Old English" ballads, tales, and speech; African American traditions in the South; Native American myths and tales; and border material from French Canada and Mexico (Newell 1888b; see also (Abrahams 1988; Bell 1973; Bronner 2002, pp. 15-19)). As with their European colleagues, they imagined that folklore in the wake of mass industrialization and urbanization needed documentation before disappearing. The organizer of the Society William Wells Newell defined folklore by its "character of oral tradition" rather than by its nationalistic roots. As he explained, "Lore must be understood as the complement of literature, as embracing all human knowledge handed down by word of mouth and preserved without the use of writing" (Newell 1888a). Newell's rhetoric along ethnic lines of "folklore in America" avoided the issue of the emergence of national lore that would have been signified by "American folklore." His delineation of groups implied at once the dominance of the British inheritance and the multiple racial-geographical influences on the formation of the United States.

Following the evolutionary thinking inspired by Charles Darwin that "higher forms can only be comprehended by the help of the lower forms, out of which they grew," Newell posed basic questions as to whether lore in America arose independently from Old World and native sources or from emerging streams of tradition in the New World: "What is the reason of the many coincidences between Old World mythologies and the legends of the New World? Do they result from the common procedure of human imagination? Or did the currents of an early tradition flow also through the American continent?" (Newell 1889, p. 2). The distinctions for investigation on the continent were racial or historical; the task of collection was to recover literary remnants surviving in North America. The analysis he suggested was oriented toward reconstructing a natural history of civilization that could explain the evolution of cultural forms from savage to civilized society.

Newell's push for America as a setting for collecting "fast-vanishing remains" of ethnic expressions did not go far enough to chart a national culture for his fellow Cambridge, Massachusetts, product Charles Montgomery Skinner (1852-1907). Skinner was one of a rising generation of Americanists who connected the protection of culture with the conservation of nature. Other prominent figures included George Bird Grinnell (editor of Forest and Stream and author of Pawnee Hero Stories and Folk-Tales [1889] 1961) and Henry Wharton Shoemaker (newspaper editor, author of Pennsylvania Mountain Stories [1911], and later the nation's first official state folklorist), and both of them had literary as well as progressive political interests. They shared a view of the Americanizing influences of the land; mixing and living in the awe-inspiring environment, diverse settlers were certain to gain a new identity called American. Even if America lacked an ancient mythopoeic age, they argued, the distinctive, diverse landscape-its wilderness, plains, rivers, and mountains - inspires legend and a spiritual connection of Americans to their natural Edenic environment (Bronner 1996; Evans 1996; Grinnell [1889] 1961). The threat to this link was unrestrained industrialization, and Skinner witnessed its effect as a journalist for the Brooklyn Daily Eagle in the late nineteenth century. He read in legends of the land a cultural grounding for Americans, a common bond among them despite their social diversity. Mining printed sources, he called his first popular collection Myths and Legends of Our Own Land (Skinner 1896) (see also Dorson 1971b). The addition of "own" created a double meaning of the land as nature and nation. Although he included aboriginal legends as part of 
"our ... land," his volumes implied that the indigenous lore had been channeled into the cultural identity of a new composite American.

The folkloristic Americanists had as a supporting voice President Theodore Roosevelt (1858-1919) who believed that the soil, and the grounding it represented for the flowering of American civilization, were nowhere more evident than in folklore. Enamored with the West and the hardy rejuvenating values it generated, Roosevelt while in the White House (1901-1909) was especially taken with the effort of Texas folklorist John Lomax (1867-1948) to collect cowboy songs (Porterfield 1996, pp. 130, 150-52). The president became excited at the prospect of the material being elevated to the status of the ancient European sagas he admired so much as a student of classics (Roosevelt 1926a). He also was astute in realizing that these sagas became national symbols as well as sources of literature as they persisted through oral tradition. As a nationalist political leader, he had been looking for a mythology for America that would be "different from all of the peoples of Europe, but akin to all" (Roosevelt 1926b, p. 330). Although noting the special connection of the United States to England because of a shared language, he considered American culture to be unique because of "new surroundings, and the new [racial and ethnic] strains in our blood interact on one another in such fashion that our national type must certainly be new" (Roosevelt 1926b, p. 330). The pioneer experience in the expanse of the West, he thought, loosened old ethnic and regional ties and reconstructed them into a "medley" sounding an enlivened American identity. In the oral tradition of cowboy songs resonating with high mountains, grand rivers, and vast plains of the frontier and rugged characters on bold adventures, Roosevelt heard keynotes stirring his robust national type. More than the pietistic New England Puritan or the passive Midland yeoman farmer, the cowboy represented the legacy of the frontiersman who in Roosevelt's eyes was the exemplary heroic figure responsible for the racial triumph of subduing the inferior "savage red man." He called the conquest of the Indians in the West "the great epic feat in the history of our race" (Roosevelt 1906, p. 16; see also (Gerstle 1999, p. 1283)).

Reacting to the perception of cowboy songs by ballad professors and public alike as crude and valueless, Lomax originally wanted to call his book Cowboy Songs of the Mexican Border to raise connections to Sir Walter Scott's Minstrelsy of the Scottish Border (1802) (Porterfield 1996, p. 147). One can read the epic comparison in Lomax's romantic characterization of the cowboy as a literary folk type: "Dauntless, reckless, without the unearthly purity of Sir Galahad though as gentle to a pure woman as King Arthur, he is truly a knight of the twentieth century." (Lomax 1934, p. xxxix). In response to those in "so-called polite society" who were repelled by the American cowboy's crudity, Lomax claimed a "Homeric" quality to the frontiersman's unfettered poetic style. He admired the cowboy's democratic freedom of expression, his earthy artistry, his unabashed outspokenness from the "impulses of his heart" (Lomax 1934, p. xxx). Intoning the American soil, Lomax declared that the songs "sprung up as quietly and mysteriously as does the grass on the plains" (Lomax 1934, p. xxv). Roosevelt helped romanticize the image of the cowboy as America's folk hero with an endorsement of "the real importance to preserve permanently this unwritten ballad literature of the back country and the frontier" as representing "our own national soul" (Lomax 1934, pp. vii-viii). Again sounding the nationalistic keynote of "our own," Roosevelt extolled the "appeal to the people of all our country" from the example of expressive and earthy cowboy lore, if not a poetic peasant class. Taking this cue, Lomax called his second volume of American ballads and folk songs Our Singing Country (Lomax and Lomax 1941). It included material from lumberjacks, teamsters, railroaders, hobos, miners, and southern farmers in addition to cowboys and with its subtitle of American Ballads and Folk Songs described the living traditions collectively as distinctively American rather than "vanishing remains" of folklore found in America.

Other Americanists resisted taking a path of touting the gritty lore of the frontier experience to follow in the footsteps of European romantic nationalism. In Philadelphia, a chapter of the American Folklore Society appeared more concerned with charting America's multicultural mix and the emergence of new community traditions. Reflecting the spirit of William Penn's "Holy Experiment" of pluralism and tolerance, the Philadelphia society's guide to local collectors stressed folklore more broadly than relics of "oral tradition" and viewed it as more representative of America's 
diverse contemporary cultural tapestry than the academic evidence of classical history and literature. The guide offered folklore as "the collective sum of the knowledge, beliefs, stories, customs, manners, dialects, expressions, and usages of a community which are peculiar to itself, and which, taken together, constitute its individuality when compared with other communities." Its approach was to consider the separation of "every community ... from its neighbors by numerous peculiarities, which, though they may at first seem trivial, exert in their mass a powerful influence on the life of the individual and the history of people in the aggregate, or the 'folk'" (Philadelphia Chapter of the American Folklore Society [1890] 1987, p. 71). The communities that it charted for collection were the "Anglo-American," "Africo-American," and "Local Foreign," comprising the Chinese "quarter," Italian "quarter," German "quarter," international sailors, and "Gipsies." The chapter sketched out its driving principle of explaining how these separate communities maintained their distinctiveness while having a national identity. Folklore was to them "an aid to the just appreciation of the various elements which go to make up a nation" (Philadelphia Chapter of the American Folklore Society [1890] 1987, p. 71). Along these lines, Lee J. Vance writing before the start of the twentieth century in the popular magazine Forum on "The Study of Folklore," argued that the United States diverged from other national humanistic legacies by providing a living laboratory for investigating multicultural progress. "Our folk-lore is highly composite," he wrote, "resulting from the great tides of immigration which have rolled over our shores and formed our present strange commingling of races" (Vance 1896-1897, p. 251; see also (Dundes 1964)).

Later social movements beyond immigration spurred folklorists to further atomize the use of folklore as adaptation to myriad social situations that one encounters in modern life. In so doing, folklore was not restricted to a lower level, past epoch of society, or oral communication. Folklore in this view resulted from social interactions in which practices-including gestural and material-identified a connection among participants and provided them a sense of tradition. The emphasis on identity gained from social interaction and expressed through folklore meant that mobile individuals could belong to many groups simultaneously and those groups were not limited to certain types associated with an ideal community. Indeed, a research question that American folklorists were particularly interested in was how folklore created the group rather than merely reflecting it. Folklorists such as Alan Dundes, Jay Mechling, Michael Owen Jones, and Elliott Oring presented corporate secretaries, organized Boy Scouts, factory and office workers, and friends and couples as folk groups in the midst of mass society, respectively, to represent American folklore as much as romanticized, isolated cowboys (Dundes and Pagter 1978; Mechling 2001; Jones 1987; Oring 2012). These folklorists designated social categories involving folkloric production that can be temporary, overlapping, and emergent in someone's life. Folklore in this view is continually emergent, and collection is therefore not about recovery of perishable, canonical texts but instead involves recording the processes by which folk practices arise in a variety of changing contexts. Although often downplaying the "essential" Americanness of this behavior, the approach developed largely in the United States built on the openness and mobility of American capitalist society, the image of a vast diversity of settings and groups in city as well as country (and suburbs), and the perception of individual freedom of expression and movement in a modern democracy.

In the remainder of this essay, I chart in more detail the different avenues for representing folklore of the United States: (1) Folklore as a Reflection of Native and Indigenous Cultures, (2) Folklore as a Sign of Transplantation and Adaptation from the Old World, (3) Folklore as a Force in the Development of City, State, Region, and Nation, and (4) Folklore as Process in Everyday and Ceremonial Life. The sequence follows an historical outline of American folklore scholarship. It reflects the centrality of the main questions or problems posed beginning in the seventeenth century. In each of these sections, I discuss the ways that the main issues folklorists took up affected the content and categories of folklore as "American" as well as informed the explanations for folklore's role and function within American scenes. I contend that these issues and the growing disciplinary identity of folklorists through the twentieth century posed profound challenges to prevailing elitist trends of the classical 
humanities and influenced the evolving democratization of expressive culture and its scholarship in the twenty-first century.

\subsection{Folklore as a Reflection of Native and Indigenous Cultures}

Probably the first public realization of folklore in what is now the United States came after distribution of Roger Williams's A Key into the Language of America (1643). His title implied that the natives were American by their indigeneity and they were folkloric because of the difference they exotically displayed from the European settlers, who Williams assumed constituted a normative culture. Conceived as a dictionary to foster communication with the Narragansett natives surrounding the Puritan settlement after he left the colony to form the Providence Plantation in 1636, Williams added to a translation of terms observations of the use of phrases and terms in customs and rituals. For example, to the word Kihtuckquaw for a marriageable virgin, Williams noted that the natives identify them "by a bashfull falling downe of their haire over their eyes" (Williams 1643, p. 29). He indicates the general name they call themselves translating to what he calls "Folke" or broadly "people" (Williams 1643, p. 8).

As to the question of the natives' origin, Williams gives a belief narrative in their own words of having "sprung and growne up in that very place, like the very trees of the wildernesse" (Williams 1643, p. 9). He reports mythological beliefs comparable, he writes, to the English narratives of Adam and Noah and refers to origin myths of earth's creation by the "Great God Cawtantowwit" (Williams 1643, p. 9). Although asserting that the natives were indigenous to the region, he contemplated the etymological legend held by settlers that the Narragansett were one of the lost tribes of Israel by noting that they possess words "to hold affinitie with the Hebrew. Secondly, they constantly anoint their heads as the Jewes did. Thirdly, they give Dowries for their wives, as the Jewes did" (Williams 1643, p. 6). Furthering the biblical metaphor, he considered the English Gentiles dwelling in the tents of Shem (the Jews) and therefore the English should be sympathetic and morally respect their civil rights (Williams 1643, p. 13). In writing of their "religion, customes, manners, etc.," he found their lore to be complex and worthy of respect. ${ }^{1}$

Curiosity about native languages sparked considerations of their use in narratives and songs into the nineteenth century. The uncovering of myths, songs, and tales by non-native collectors was important in American society because of its suggestion of an oral artistry tied to complex religious systems (see Heckewelder [1818] 2016). Prominent among such figures presenting native lore to the American public was Henry Rowe Schoolcraft (1793-1864). While serving as a United States Indian agent in Michigan in 1822, he married Jane Johnston, a woman of Ojibwa background who came to be known as the first known Native American literary writer, and learned the native language. Captivated by her native culture, he gathered folk songs and stories in the original language from his wife's family and then expanded beyond them to collect material on numerous tribes. The Schoolcrafts established as an outlet for this material the magazine The Muzziniegan or Literary Voyager (1826-1829), often considered the first serial publication in America of ethnological and folkloristic material (Bremer 1987; Clements 1996). Disrupting views of the natives as savage and backward, Schoolcraft wrote that native "oral stories are, generally, very extravagant, often of an allegorical character, and sometimes they even aim at instruction. They are the true presentments of the Indian mind, and show more than any other species of inquiry, or research, their opinions and beliefs on life, death and immortality" (Schoolcraft [1859] 1986, p. 56).

Famed American poet Henry Wadsworth Longfellow (1807-1882) took notice of Schoolcraft's sources and composed "The Song of Hiawatha" (1855) based upon stories of an Ojibwa trickster figure Manabozho (or Nanabozho) (Thompson 1922; Schramm 1932; Osborn and Osborn 1942; Davis 1957). While Longfellow envisioned the story as an epic for America, lacking among the literature

1 The long subtitle of his book with a reference to customs and manners was, Or, An help to the Language of the Natives in that part of AMERICA, called NEW-ENGLAND. Together, with briefe Observations of the Customes, Manners and Whorships, etc. of the aforesaid Natives, in Peace and Warre, in Life and Death. On all which are added Spirituall Observations, Generall and Particular by the Authour, of chiefe and special use upon (upon all occasions,) to all the English Inhabiting those parts; yet pleasant and profitable to the view of all men. 
of the European settlers, Schoolcraft referred to the Ojibwa narratives more modestly as part of native "cabin lore" consisting of songs, tales, and myth told in domestic rather than ritual settings. Schoolcraft noticed aspects of a folk hero cycle in the figure's miraculous birth and performance of what he called "the most extravagant and heroic feats" (Schoolcraft [1839] 1992, p. 134). For example, he related the belief that Manabozho came from mythical parentage. His grandmother was reputedly the daughter of the moon. A rival tricked her toward a grapevine swing by a lake, and then pitched her into the water and she fell through to the earth (Schoolcraft [1839] 1992, p. 135). Schoolcraft noticed similarities in other tribes, and although he noted "peculiarities" of customs in each group, he posited a cultural connection among native Americans as a result of migrations and interchanges from the Southwest to the Northeast. Other observers thought a more likely source was in Asia from migrations across the Bering Strait and down into the continent (Schoolcraft [1839] 1992, pp. 21-26. See also (Brownell 1864, pp. 15-18; Kennedy 1856)). They looked for evidence of similarities to southwestern folklore in narratives and customs collected from groups such as the Chukchi of northeastern Asia and Chinese further south (Dixon 1993; Ives 1956; Laughlin 1977; MacCurdy 1915). In this view, the European settlers constituted the latest migration of people and culture into the huge, mysterious expanse known as North America and they had as much right to the land, if not more so, as the previous inhabitants.

The status of Native American lore claimed by some folklorists as indigenous, unique among the world's mythologies, and as worthy of social and literary adulation entered earlier into debates among American leaders about the representation of the New Republic. Some members of the revolutionary generation thought that the lack of a mythology, and a distancing from the native culture of Indians, was a virtue for a country seeking in historian Richard Slotkin's words, "to be liberated from the dead hand of the past and become the scene of a new departure in human affairs" (Slotkin 1973, p. 3). Other early nationalists advocated for Native American lore to be integrated into the symbolism of the United States as a sign of its distinctive cultural legacy, and future manifest destiny (Fleming 1965). Conceived by writer James Fenimore Cooper as a vernacular "leatherstocking" or pioneer figure, the new American incorporating folklore of the native idealized harmony with nature and an adventurous free spirit (Smith 1970, pp. 59-70). Indeed, even before the revolution until the early nineteenth century, the image of the "Indian princess" graced illustrations of the emerging country, before transforming into a Greek goddess representative of a new classical civilization (Fleming 1967). Although folklorists and writers reveled in the newfound mythology of Native Americans, detractors such as classicist Hubert M. Skinner (1855-1916) argued that "The mythology of ancient America is meager, and is generally of little importance in its relation to literature and art [especially to classical Roman and Greek works], though it possesses considerable interest in connection with geographical names and local traditions" (Skinner 1893, p. 15).

Another argument since the outbreak of "Indian wars" in colonial New England in the second half of the seventeenth century was waged in emergent folk narratives. Colonists published legendary accounts of women captured by bloodthirsty "pagan savages" that stirred hatred, and elimination, of the natives, while tracts by travelers noted their spiritual, benevolent nature evident in elaborate songs and stories. The colonists' tracts followed different mythological references before and after the wars (Slotkin 1973, pp. 94-145). Previously, writers depicted English colonization following the plot of the biblical Exodus story with the New World emerging as the Promised Land. The captivity narratives used the "lost people" legend of Babylonian captivity with exile from a corrupted England in place of the land of Israel. In these new narratives, the Indians as natural beings were depraved creatures who could not be turned to God or government. French writer Alexis de Tocqueville in his major tome Democracy in America (Tocqueville [1835] 1966) noted that the narratives influenced settlers to hold natives in an "inferior position in the land where they dwell" and have them suffer "the effects of tyranny" (Tocqueville [1835] 1966, p. 317).

Horatio Hale, who followed Schoolcraft with folkloristic studies of native myths, vouched for Native American morality by arguing that the Indians were no more war-like than the Europeans. 
He wrote "The persistent desire for peace, pursued for centuries in federal union, and in alliances and treaties with other nations, has been manifested by few as steadily as by the countrymen of Hiawatha." (Hale 1881, p. 20) He even drew comparisons to the deeply spiritual as well as artistic renderings of their mythology by affirming that "The sentiment of universal brotherhood, which directed their polity, has never been so fully developed in any branch of the Aryan race, unless it may be found incorporated in the religious quietism of Buddha and his followers" (Hale 1881, p. 20). For some writers, the connection of mythology to an ancient history made a claim for Native Americans as an ethical civilization. An important text from the viewpoint of a Native American was David Cusick's Sketches of Ancient History of the Six Nations (1828) written by Tuscarora artist David Cusick (c. 1780-c.1831). It included edifying myths for the creation of the universe and the "Great Island, now North America" (Cusick 2006, p. 5). Cusick referred to the northeast Iroquois confederacy with familiar terms of civilization such as "kingdom" and "nations" (see Kalter 2002).

Francis La Flesche (1857-1932) became the first professional Native American folklorist in the Bureau of American Ethnology at the Smithsonian Institution (Alexander 1933; Alexander 1982; Parins and Littlefield 1995). Working closely with president of the American Folklore Society (AFS) Alice C. Fletcher (1838-1923, president of the AFS in 1905), on the Omaha culture into which he was born on a reservation, he focused on the distinctive aspects of rituals, songs, and stories within the tribe (La Flesche 2013; Fletcher and Flesche 1911). He dispelled notions of natives as simple children of nature and illuminated the highly complex systems of tradition at work. He and Fletcher argued for the diversity rather than unity of Native American cultures in the United States, as was evident in comparative fieldwork they conducted with the nearby Osage. In an essay, "Who Was the Medicine Man?" for the Journal of American Folklore in 1905, he criticized missionaries many of whom wrote on the folklore of the Native Americans by declaring "the idea commonly entertained by the white race that they alone possess the knowledge of a God has influenced the mind of all those of that race who have come in contact with the Indians ... So, when they happened to see the Indians worshipping according to their own peculiar customs, using forms, ceremonies, and symbols that were strange, they said, 'Poor creatures, they are worshipping the devil!' when in truth the Indians never knew a personal devil until he was solemnly and religiously introduced by the teachers" $(1905,269)$. He also railed against many white ethnologists, who presented the myths and rituals they collected appear "childish or as foolish" (La Flesche 1905, p. 270). These were principles that Franz Boas as mentor to many budding folklorists and anthropologists at Columbia University and editor of the Journal of American Folklore applied in insisting on the historical particularism of each group and understanding of narratives in the language in which it is performed (Boas 1915; Boas 1938. See also (Darnell 1973)).

In the twentieth century, a governmentally sponsored salvage project was apparent to record stories, songs, crafts, and rituals from Native Americans because of the assumption that tribal culture had largely vanished. The Bureau of American Ethnology in the Smithsonian Institution assigned fieldworkers to record remnants of folk tales and songs from native elders. More interventionist were Indian boarding schools established by the Bureau of Indian Affairs to "Americanize" native children. In addition, missionaries continued to convert Indians to Christianity and discourage native folk practices that presented rival folk religious beliefs. Thus anthropologist Alfred Kroeber of the University of California, Berkeley, created a national sensation when he declared a member of the Yahi tribe he named Ishi (for "man" in the Yana language) the "last wild Indian" in America. He recorded folk stories and songs from him with the implication that all subsequent collections of folklore represented the dominance of Euro-American culture (Kroeber 1961; Sackman 2010).

However, folklorists such as Barre Toelken, adopted by a Navajo family in 1955, found a persistence of folklore and adaptation of new traditions that he analyzed in terms of identity maintenance within, and apart, from a larger American society (Toelken 2003). In addition to recording texts comparable to those in nineteenth-century anthologies usually amassed from elders, folklorists also considered uses by children of belief systems of social control such as the "skin-walker" (a witch-like figure who shift into animal form), performance styles and structured communication 
(such as the reliance on four episodes rather than three in European narratives) underlying emergent lore such as jokes and legends, and pan-Indian expressions and contexts for folkloric practice such as powwows (Brady 1984; Browner 2002; Cunningham 1992; Green 1996; Jackson 2003). In these studies, scholars reminded readers that Native American lore remained in the living tradition of the United States. Reversing the lens on white society, folklorists also drew attention to rhetorical uses of Native American figures and supposed "Indian legends" in contemporary contexts such as college campuses that supposedly were built upon hunting or burial grounds of Indians and summer camps that drew upon the natural metaphor of Indians to connect campers to awareness of non-technological life (Green 1975; Tucker 2007a, pp. 153-81).

A post-modern phenomenon also attracting scrutiny with implications for American cultural identity breaking with the oppressive or colonial past was the appropriation by Euro-Americans of Native American folklore to shape hybrid spiritual traditions within religious movements variously called New Age, New Religion, and neo-Shamanism (Wernitznig 2003). Folklorists note the influence of popular texts such as Black Elk Speaks (1932) written by a non-Native concerning an Oglala Lakota medicine man and The Teachings of Don Juan (1968) concerning an apprentice's experience with a Yaqui shaman (Black Elk [1932] 1988; Castaneda 1968). In both cases, folklorists questioned the authentic textualization of the narratives integrated into New Age movements and opened up anew issues of presentation (and translation) raised by the Grimms (DeMallie 1993; Mille 1980; Junquera 2005; on textualization, see (Clements 1996, pp. 17-30; Honko 2000)).

Biographical approaches to active contemporary bearers of tradition such as Barre Toelken's "consultant" (rather than the more passive, and less authoritarian sounding noun "informant" used by many fieldworkers) supplemented earlier campaigns to inventory native texts with life-story recording (Francis 2016; Radin [1920] 1963; Toelken 1998; see also (Titon 1980; Workman 1992)). The movements tend to emphasize universal symbols evident in Native American mythologies, although folklorists typically examine the localized cultural contexts in which they appear. Rather than dismiss the New Age movements, however, several folklorists have considered the application of Native American folklore in social movements as evidence of a long process of cultural exchange and appropriation since Roger Williams's dictionary appeared and drew attention to the complex political relationships between natives and settlers.

\subsection{Folklore as a Sign of Transplantation and Adaptation from the Old World}

While Americans of European descent understood through various popular anthologies the association of Indians with indigenous tradition, in the rising cities of New York and Philadelphia they primarily mused on the creation of a national culture out of the mix of various immigrant groups from Europe. Influential on this development was John Fanning Watson (1779-1860). In Annals of Philadelphia and Pennsylvania in the Olden Time (1830), Watson found what he called "traditionary lore" (including local legends, customs, and beliefs) that in his view arose from the settlement experience rather from transplantation from Europe (Watson [1846] 2009, p. 368; Watson 1857, 2:12). Even the Germans who came in large numbers to Philadelphia in the eighteenth century, and formed their own communities, Watson observed, created a New World hybrid in a dialect and lore that was distinct from their roots in Germany while blacks showed little evidence of their African tribal origins (Watson 1857, 1:254-58). His comments were part of an ongoing debate not only to issues of an Americanizing process out of the mixing of different national ancestries abut also about the resistance to enslavement and oppression of African Americans through the retention of their traditional practices. Instead of arguing for turning back industrialization, Watson's hope was for maintaining continuity with the spiritual values of the past as American society underwent material changes (Watson 1857, 1:261-64, see also (Vaux et al. 1974)). Fearing for the loss of this oral tradition in the wake of further modernization, he called for its immediate recovery and for creating for America what Sir Walter Scott had accomplished for Scotland with his folklore collections and the literature it inspired (Watson 1857, 1:10-12). Understandably, Washington Irving, who was tapping the lode of 
folklore around his upstate New York home to produce an American literature, applauded Watson's call. Irving invoked a grounding metaphor to support him: "He is doing an important service to his country, by multiplying the local association of ideas, and the strong but invisible ties of the mind and of the heart which bind the native to the paternal soil" (Watson 1857, 1:vi-vii). The "native" for Irving, however, was the European settler.

Watson's argument for applying the techniques of Scott to a new environment such as the United States was that America had gone through as many changes in a generation as Europe had in hundreds of years. He wrote, "A single life in this rapidly growing country witnesses such changes in the progress of society, and in the embellishments of the arts, as would require a term of centuries to witness in full grown Europe" (Watson 1857, pp. vi-vii). Sharing the stage with Schoolcraft at a ceremony in Philadelphia to honor William Penn's establishment of religious tolerance in his "Holy Experiment," Watson related stories handed down to European-American residents of Philadelphia about long-gone, ghostly Indians. He could not find myths to equal those in Schoolcraft's collection, but he offered beliefs, sayings, and stories that he said represented the formation of a new society out of the mixed multitude of immigrants who came to Philadelphia. He felt he had to defend this material, since to his eye, and ear, it lacked the exoticism, artistry, or antiquity of European folk literature, especially its fairy tales and epics. The Americanness of folklore was most evident in the response of legendry for historic personages and the diverse flora, fauna, and landscape features of the country (Watson 1857, 1:2).

For the founder of the American Folklore Society William Wells Newell (1839-1907), dominance of the "Old English" inheritance in the United States was especially evident in children's games. His thesis was that while these traditional games were disappearing in the British Isles, they thrived in the environment of the United States and came to characterize American play. He explained that "The influence of print is here practically nothing; and a rhyme used in the sports of American children almost always varies from the form of the same game in Great Britain, when such now exists" (Newell [1884] 1992, p. 2). Aware of the great influx of immigrants from eastern and southern Europe, he observed that they assimilated to the English-based normative culture. He wrote that "the children of these immigrants attend the public school, that might engine of equalization; their language has seldom more than a trace of accent, and they adopt from schoolmates local formulas for games, differing more or less from those which their parents used on the other side of the sea" (Newell [1884] 1992, p. 2). He referred to immigrant children who speak German in their homes, and play games from "the Fatherland" among themselves, but in contact with English-speaking children, they resort to a common repertoire of English-derived games, including "London Bridge is Falling Down," "Follow the Leader," and "Ring around the Rosie" (Newell [1884] 1992, p. 2). Challenging this view, children's folklore specialists pointed out strong non-English traditions in African-American ring and clapping games ("Loop de Loo," "There's a Brown Girl in the Ring," "Hambone," "Juba"), Pennsylvania-German ball games ('corner ball"), and Chinese divination and gambling games (dominoes, backgammon, dice) (Brown 1974; Culin 1890; Culin 1891; Jones and Hawes 1972). Yet these were ethnic groups that had been isolated either because of segregation or settlement patterns.

A similar thesis held for balladry. Folklorists maintained that British folk ballads persisted longer and showed wider variation in the United States than in the British Isles, especially in isolated mountain regions such as the Appalachians and the Ozarks primarily populated by settlers of British background. American-born Olive Dame Campbell (1882-1954) and Englishman Cecil Sharp (1859-1924) sparked a song-collecting fervor to uncover this hidden trove with the publication of English Folk Songs from the Southern Appalachians (1917). Campbell and Sharp reported ballads performed widely in the Appalachian region such as "Barbara Allen," "Lord Randall," and "Fair Margaret and Sweet William" that Harvard professor Francis James Child had assumed were extinct (Sharp and Campbell [1932] 1966). There were differences in the American corpus, however. Repertoires tended to take away aristocratic references and singers tended to downplay supernatural content. The existence of the British ballads, collectors found, was not just an Appalachia and Ozark 
mountain regional phenomenon. "Child ballads" so named after the delineation of 305 types in the literature professor's The English and Scottish Popular Ballads (Child [1882-1898] 1965, 5 vols.) were reported from Maine to Florida and New York to California in the twentieth century. ${ }^{2}$

A number of twentieth-century folklore projects sought, on the one hand, to document non-English folksong repertoires to demonstrate the persistence of ethnic cultures in America and, on the other, identify songs that emerged on American soil to show that the American folk repertoire was not all derivative. Among the emergent singing traditions that indicated cultural resistance to assimilation were Mexican corridos in the Southwest, Pennsylvania German secular songs, Creole and Cajun songs of Louisiana, and Yiddish folk songs (Rubin 1973; Buffington 1974; Paredes 1976; Spottswood 1990; Vernon 1995; Saxe 1997; Mlotek and Slobin 2007; Sánchez 2006). Folklorist George Malcolm Laws (1919-1994) devised an index of "native American ballads" including Lomax's cowboy songs (Laws A4 "Cowboy's Lament" and B9 "Sweet Betsy from Pike") and war sagas (Laws A4 "Paul Jones's Victory" and "Brave Wolfe," Laws A7 "Battle of New Orleans") (Laws 1964). He added other robust categories for ballads of lumberjacks, sailors, outlaws, murder, and disasters. The only ethnic category was for African Americans. It included distinctive American folk songs, many of which entered into popular culture, such as "Stagolee" (or "Stackolee"), "John Henry," and "Railroad Bill".

The significance of the index beyond its classification system was the announcement of a large body of incipient traditions that could be called distinctively American. This body of work was relative to the emphasis in folksong scholarship on the older British corpus of song. Laws often took sides in arguments over the identification of some songs as American or British. An example is the song "Little Mohea" (H8) about a sailor who is tempted by the lure of Mohea, an "Indian lass." He tells her that he is committed to his "true love" across the sea. Upon his arrival he finds that this love has been unfaithful and he longs for Mohea (also Mohee). Laws lists it as an American ballad, citing Philips Barry's theory that it was originally a story of romance between a frontiersman and a native maiden and then the scene changed when it became a sea song with the Hawaiian island of Maui (cf. Mohea) as a setting. Laws acknowledges folklorist George Lyman Kittredge's assertion that the song derived from a British broadside with the presumption that the print source predated the American version, but Barry argued that the American ballad inspired the British broadside (Laws 1964, p. 224). ${ }^{3}$ Beyond the academic argument over the song's genesis are the stakes in the debate of legitimizing a distinct rather than derivative folk tradition that arose from the peculiar conditions of the American experience.

If Child ballads could thrive in American settings, American folklorists asked, could there also be a related trove of Old World Märchen waiting to be unearthed? Folklorists indeed found versions in Appalachia and the Ozarks of well-known European tale types such as "Bluebeard's Hidden Chamber" (ATU 312) and "The Youth Who Wanted to Learn What Fear Is" (ATU 326). ${ }^{4}$ The wonder-tale material could also be heard beyond the isolated mountaineer homes, however. The Sorcerer's Apprentice (ATU 325) and Snow White (ATU 709) headed a collection of stories taken from Pennsylvania Germans in the 1940s (Brendle and Troxell 1944, pp. 15-22). Folklorists excitedly reported a variant of Snow White as "Snow Bella" among Louisiana Cajuns, and in New England and New York they located Old World stories of fairies and "little people" from descendant of Irish immigrants (McCarthy 2007, pp. 173-80, 376-86). Out west, folklorists recorded narratives incorporating "The Princess Who Cannot Solve the Riddle" (ATU 851) from Mexican-Americans, and "The Dragon Slayer" (ATU 300) and "The Clever Precepts" (ATU 910) from settlers of old European stock (De Caro 2009, pp. 60-63, 116-20).

2 For surveys of the British folk ballad in North America, see (Coffin 1977; Dugaw 1995; Laws 1957; Pound 1922; Scarborough 1937). For historiography of the ballad collecting movement, see (Spencer 2012; Wilgus 1959).

3 The song is also indexed in Robert Waltz's ballad index as LH08 and he lists an extensive list of sources: http:/ / www. fresnostate.edu/folklore/ballads/LH08.html. The Roud Folksong Index lists it as no. 275: http://www.vwml.org/search/ search-roud-indexes. See also (Fife and Redden 1954); "Little Mohea" is discussed on pp. 382-84.

4 ATU (Aarne-Thompson-Uther) numbers refer to the standard reference used by folklorists to designate international tale types: (Uther 2004). For versions from Appalachia and the Ozarks, see "“How Toodie Fixed Old Grunt” (ATU 312 Bluebeard) and "The Boy That Never Seen a Fraid" (ATU 326 The Youth Who Never Learned Fear) in (De Caro 2009, pp. 63-65, 88-89). 
The most noticeable catch in the American folklorist's net was a slew of "Jack tales," many provided by the Hicks and Harmon families in North Carolina called by folklorist Carl Lindahl, "the nation's most celebrated storytelling family" (Lindahl 2004, pp. 1-58; see also (Isbell 1996; McCarthy 1994)). The Hickses came from England and the Harmons from Germany in the eighteenth century. In subsequent generations into the twenty-first century, the stories of a boy-hero named Jack who outwits giants, witches, and demons were among the most memorable and lasting. In the twentieth century, a number of popular books such as Richard Chase's The Jack Tales (1943) and complementary recordings spread notice of the tales as an American expression primarily associated with white southerners (Chase 1943; Chase 1950; Shipley 1982; Davis 1992; Haley 1992; Perdue 1987; Perdue 2001). Although the story of "Jack and the Beanstalk (Giant)" (ATU 328A) is most popularly known, a great number of variations spun around the character emerged. A story attached to the performance of Ray Hicks (1922-2003), called by Lindahl "the most famous traditional storyteller in America," went by the name of "Jack and the Robbers" (ATU 1525A). It involved a boy who confronted by robbers who want to kill him has his life spared by pointing out to the robbers that "I ain't got nothing, all my little rags is all. I'm just a poor little humble boy" (Lindahl 2004, p. 135). The robbers offer to let him go if he steals three animals, which he does, and then gets paid by the thieves. Unlike European narratives in which the boy's test is stealing from an aristocrat, in Hicks's version it is a farmer. Although coming from European tradition, the indigent, scrappy Jack became an American stock figure and a Hicks favorite because of his overcoming challenges out on his own. He appeared to epitomize the rugged, resourceful individual who triumphs over larger forces that challenge doubt him (Lindahl 2004, pp. 131-38).

Another set of narratives, sometimes set as marvel tales, sometimes as legends, center on the search for treasure (De Caro 2009, pp. 287-93; Dobie 1931; Granger 1977; Moore 1986). Whether hidden because of fabled pirates, eccentric misers, or lost mines, the stories frequently end with the treasure eluding the seekers. Sometimes the treasure has a curse attached or disaster befalls the treasure-hunters. Folklorist Alan Dundes drew a contrast between treasure narratives in the United States and those reported in Mexico to make a point about the way that stories reflected, or reinforced, American values (Dundes 2007; see also (Foster 1964)). He noted that Mexican collections had an outcome of the treasure being found, often to explain the source of a community member's rise in social status. Dundes posited that these patterns could be called "folk ideas" that constitute different worldviews. The Mexican pattern indicates an "image of limited good," an outlook of fatalism related to the lack of social mobility. If someone is able to rise in status, community members imagine that it was as a result of coming into good fortune through luck. Dundes interpreted the American narrative of not finding treasure reflects as an "image of unlimited good." This folk idea expresses the individualistic, optimistic view that wealth is expandable and therefore people can increase their social status by working for it. An American proverb that expresses this idea is "work hard and you shall be rewarded." Seeking the treasure, or hoping for luck, in this American worldview, is discouraged; individuals should be able, expressed proverbially, to "pick themselves up by their own bootstraps," "if at first they don't succeed, try, try, again," and "the more practice they have, the luckier they get."

The pattern of finding of treasure in folktales of the United States did not mean that supposedly pragmatic Americans did not value, or have beliefs about, luck. The pervasiveness of lucky numbers such as 7, and the unlucky 13, in contrast to fortune attributed to eight in Chinese culture (but four is considered unlucky in Chinese because it is homophonous with the word for "death"), for example, attest to the persistence of distinctive Western-derived belief systems in the United States. Considering the rise of customs surrounding mid-life crisis at the age of forty in the United States in the twentieth century, anthropologist Stanley Brandes (1985) thought that the idea of forty as a significant quantity representing the end of life, had roots in biblical religions of the Middle East which set 40 as the number of years wandering in the wilderness and number of days and nights during the great flood, among other references. The number, or age of forty, was not statistically a mid-life point in the United States but had been culturally constructed as a special number multiplying four with its symbolism of being more than enough (three represented completeness) and ten as an official quantity. Alan Dundes 
also viewed a special status of the number three in American culture, not only in folktales for the typical number of episodes, but also in folk speech ("third time's a charm," "three Rs,: reading, 'riting, and 'rithmetic," and "three on a match") and as a basis of design (aba, or bilateral symmetry in British-American houses and gravestones) (Dundes 1980, pp. 134-59). He found that this base concept was not universal; the morphology of many Native American narratives featured four episodes, and Asian tales featured five. One interpretation of the emphasis on trichotomy in American culture is that it reflects the human body (head and shoulders) with the implication of expansive human dominion in contrast to the symbolism of four as all the cardinal points (Asian cosmology adds a fifth location in the self) (Bronner 2007, pp. 7-8).

An American belief in expansiveness is evident in the association of "tall tales" (known colloquially as whoppers, windies, or lyin' tales) with oral and visual traditions in the United States (Baughman and Holaday 1944; Blair 1944; Clough 1947; De Caro 2009, pp. 174-85; Dorson 1982; Lindahl 2004, pp. 461-86; Loomis 1945; Siporin 2000). A European tradition of comical tales referred to hyperbolic feats of a Baron Munchausen as sportsman and soldier (see Bynum 1988; Kareem 2012). In the United States, tall tales include stories of ordinary folks who because they live on the frontier describe astounding phenomena matter-of-factly, provide exaggerated accounts of fishing and hunting exploits, serve up anecdotes of "real characters" who fool their gullible audience, and relate narratives of comical demigods associated with intrepid enterprises in the expanding West. In some localities, this recognizable form of storytelling, as well as its associated attributes, are celebrated in "liars' contests" (Biebuyck-Goetz 1977; Kahn 1960; Lindahl 2004, pp. 466-70). Sometimes stories might be told using the contest to frame a competitive streak, characteristic of, or mocking, an American "nothing is impossible" attitude (and emphasis on speed in doing it). For example, folklorist Herbert Halpert reported a story from a young warrant officer who set up the story by saying "Well, there were two men arguing about how fast they were and to prove his point one of them said he went out to the well to draw a bucket of water." The trouble was that "as he started away from the well, the bottom of the bucket dropped out." "No problem," he said unaffectedly. "He ran to his house, got another bucket and caught the water before it hit the ground." And the other fellow? He said that he had been out hunting. The narrator explained that "he shot a deer and skinned and dressed it and had it hanging up in his meat house at home before the bullet left the end of the gun" (De Caro 2009, p. 181). Performance of the stories often appear humorous and suggest a literalization of the phrase "the sky's the limit." They also can belie the hardscrabble conditions of settlers who had giant aspirations but struggled mightily.

When visualized, the tall tale style is evident in doctored postcards and posters that show a giant vegetable, fish, or insect being carried by ordinary farmers with the caption "How we do things around here" (Rubin and Williams 1990; Welsch 1976). Or fantastic creatures such as the jackalope (a jackrabbit with antelope horns) would be pictured and occasionally mounted as a joke in restaurants and hotels. Its imagery often invites a story along the lines of a tall tale or a "practical joke" (colloquially known as the "put-on") (Dorson 1982, pp. 50-54; Marsh 2015, pp. 22-23). Such fantastic chimerical beasts in "these here parts," cueing folk speech, announce that the western environment produces strange, unprecedented sights and the dominant image of hybridization in the animal is typical of the social process for human residents.

Americans often festooned heroes with tall tales in addition to miraculous origin legends. Folklorist Richard Dorson claimed that the real-life Davy Crockett (1786-1836) set the stage for the irreverent character of ringtailed roarers who were admired in tall tales and composed an American mythopoeic "heroic age" during America's westward expansion into the frontier (Dorson 1942; see also (Dorson 1939)). Exaggerated as "half bear, half alligator," Crockett supposedly bragged that with a smile he could charm a raccoon down from a tree, but on one occasion he mistook a knothole for the creature's eye and grinned all the bark off (Dorson 1977, p. 204). Tellers of Crockett tall tales often spun the stigmatized vernacular of the backwoodsman into a positive, even celebrated trait, and in the process perhaps satirized the attitude of snooty Europeans or stuffy Easterners toward the 
crude American everyman. Crockett was revered for emerging victorious in a wrestling match with a mammoth bear and loving his faithful dog Teazer, who could throw a buffalo (Dorson 1977, p. 211).

In the twentieth century, characters from the worlds of industry, sport, music, crime, and military displaced the pioneer subjects of tall tales. Texas oil drillers heralded Gib Morgan (1842-1909) a modern-day Munchausen who performed miraculous feats of drilling and displayed a lust for life (Boatright 1945; Dorson 1982, pp. 126-39). Texas folklorist Mody Boatright documented at least fifty distinct tale types attributed to Morgan, including his account of patching up a dog who was split by charging into a sapling splinter. Morgan put him back together with two legs up and two legs down which thrilled the hound no end because he could outrun any rabbit in the valley by turning cartwheels (Boatright 1945, pp. 95-97; see also (Dorson 1977, p. 229)).

The twentieth century was also the era of literary folk heroes who might have a basis in folk tradition but who took a popular culture turn in newspaper columns, books, comics, and advertisements. Dorson dismissed the national rage for stories of lumbering titan Paul Bunyan and his blue ox Babe as "fakelore" invented by logging company writers and used during World War II in propaganda to stir militaristic nationalism (Bronner 2013; Dorson 1971a, pp. 3-14; Dorson 1976, pp. 1-30; Fox 1980; Stekert 1986). Questions have also arisen for others of his ilk such as Pecos Bill (remarkable southwest Texas cowboy), Joe Magarac (extraordinary Pittsburgh steelworker), and Febold Feboldson (giant Swedish American sodbuster) (Fishwick 1959; Gilley and Burnett 1998; Sheviak and Anderson 1969). Yet a case has been made into the twenty-first century for legendary strongmen and strongwomen attached to locally known characters who provide the material for humorous tall tales and awe-inspiring legends with themes of the extent of human limitations in a technological world (Bronner 2012b).

Renowned in both song and story, the African-American hero John Henry (Laws I 1; Roud Folksong no. 790) is a study in the projection of anxieties about machines replacing humans in addition to undertones of the racialized, and therefore stigmatized, laborer expressed in American folklore in addition to projecting the often stereotyped image of the hypermasculine black man. Other larger-than-life African American figures such as John Hardy (Laws I 2; Roud Folksong no. 3262), Bad Lee Brown (Laws I 8; Roud Folksong no. 780), and Stagolee (Laws I 15; Roud Folksong no. 4183) were narrated as anti-hero badmen (Bryant 2003; Roberts 1989). Their motifs of confident defiance, fatalism, and resignation to violence appeared in narrative poetry identified by African-American tellers as toasts that purportedly inspired rap and hip-hop lyrics of the twenty-first century (Bronner 2006; Orejuela 2014, pp. 46-50). According to many music historians, Stagolee (also known as Stagger Lee and Stackolee) in toast, story, and song is especially influential (Brown 2003; Middleton 2007; Polenberg 2015). With considerable bravado, performers relate his story of an unrepentant badman who shoots his old friend Billy Lyons because he beat him in a gambling game. Cecil Brown claims that as a secular oral performance of the streets contrasting with the black preacher, "Stagolee has influenced a new art form in rap music and hip-hop. As an invisible hero, Stagolee is an image of a man who can find dignity in his own country, which seeks to disgrace him" (Brown 2003, p. 225; Middleton 2007). Brown adds the theme of human limitation in an industrial world by observing "He is an allegory of the oral black man who traveled from the mechanical world and now lives in an electronic information world" (Brown 2003, p. 225). Often related in the first person, Stag (raising images of an independent "buck") is sure to fall but before he does lashes out violently at Billy and everyone else: "Yeah, I'm Stagger Lee, and you better get down on your knees and slobber my head/'Cause if you don't you're sure to be dead/Billy dropped down and slobbered on his head, But Stag filled him full of lead" (Brown 2003, p. 225; Wepman et al. 1976, pp. 134-37).

The badman figure is a contrast to, or evolution from, the African-American trickster tales made famous by white journalist Joel Chandler Harris in the nineteenth century (Bickley 1981; Bickley 1987; Brookes 1950; Chase 1955; Bickley and Keenan 1997; Brasch 2000). After the popularization of his stories related by a fictional southern plantation storyteller Uncle Remus, folklorists found evidence of Brer Rabbit trickster tales throughout the black South along with cognate figures such as Aunt Nancy and traced them to African antecedents (Light 1975; Baer 1980). Besides inviting interpretations of the tales as animal parables indicating the use of cunning by the oppressed rabbit to escape, the animal 
stories raised questions about the evidence of the tales of Africanisms persisting in the South despite the suppression of African culture. Folklorists made connections of the stories with West African trickster tales of Anansi the Spider (probably the antecedent of the homophonous "Aunt Nancy" character in black folktales of the Caribbean and Carolina coast) (Backus 1898; Piersen 1971; Bascom 1981; Roberts 1988).

Attracting close attention was the iconic "tar baby story" (ATU 175) involving a baby doll composed of tar made by Brer Fox who is antagonistic to the rabbit (Baer 1980, pp. 29-31). The rabbit approaches the tar-baby, and angered on hearing no response, punches and kicks the doll. The rabbit gets stuck and is helpless before the fox who grabs him. The trickster rabbit uses reverse psychology on the fox by pleading with him not to fling him into the briar patch. Convinced by the rabbit that landing in the briar patch is the most painful option for the rabbit, the fox heaves him there, only to find that the rabbit is at home in thickets and is able to escape. Although most studies cite an African origin, folklorists have also hypothesized a genesis in India and Iran, and possible influences from Cherokee, Meso-American, and Caribbean narratives (Baer 1980, pp. 30-31. See also (Cline 1930; Espinosa 1943; Nickels 1981; Taylor 1944)). Regardless of its derivation, the animal stories were associated with southern African-American culture and the black trickster character made appearances in later jests on the theme of "John and ole Marster" and toasts such as "Shine and the Titanic" and the "Signifying Monkey" (Abrahams 1970, pp. 97-172; Dorson 2015, pp. 124-70; Jackson 1974, pp. 161-96; Oster 1968; Roberts 1989, pp. 17-64).

Similar questions about the persistence of ethnic folk forms addressing relationships of the minority with the majority population in the United States have swirled around the Mexican-American norteño corrido (northern ballad). Often traced to medieval romances set in ballad form, corridos about folk heroes and legendary events with political overtones in the contested border region of the American Southwest circulated widely in oral tradition among Mexican-Americans. Mexican-American folklorist Américo Paredes found special significance to songs and stories of Gregorio Cortez (1875-1916) born on the Mexican side of the border but raised in Texas (Paredes 1958). "El Corrido de Gregorio Cortez" first circulated orally in the early twentieth century and continued to be sung into the twenty-first century. According to the legend that inspired the ballad, Cortez was unjustly accused of horse theft by a gringo sheriff and violence erupted when the law moved in to arrest him. A long chase ensued that added to Cortez's mystique as possessing extraordinary strength and perseverance. Stories circulated that he had walked 100 miles, ridden more than 400, all the while being pursued by posses of 300 men. Eventually Cortez was caught and put on trial. He was acquitted for the murder of one sheriff but not the other. He was sentenced to life in prison, but when pardoned by the governor, his Mexican-American admirers interpreted the events as a triumph of justice for oppressed Mexicans at the hands of gringos in the border region. Indeed, the corrido form calls for a moral lesson and farewell from the singer after giving a salutation and relating the story.

Although corridos became commercialized by recording companies and broadcast on television and radio, many folklorists point out that the folk process is still evident in an evolution of the folk hero corrido into the "narcocorrido" (McDowell 2012; Morrison 2008; Wald 2001). Emerging in the 1970s, the narcocorrido features the traditional tripartite corrido structure of salutation, description of events, and moral lesson to relate legends of fabled drug smugglers and dealers and their brazen exploits. Folklorists listen for circulating motifs in the lyrical content within the context of shared folk performance styles. For example, in 2015 when drug lord Joaquin "El Chapo" Guzman escaped from Mexico's most secure prison, songs quickly circulated outside of media outlets that portrayed him as a Robin-Hood figure, rags to riches mythology, his braggadocio in declaring that the authorities could not keep him, and his vanity, or cunning, in escaping without messing up his hair (Martinez et al. 2015). Ambivalence could be heard in the moralizing typical of the genre, including questioning the power, and obsession, with having more money than one could possibly use. As with other popular expressions of ethnic groups with a persistent community presence, folk aspects are couched within an older tradition and the content compared with earlier themes, often to bring out the resistance to assimilation and hybridization with other traditions within the massified American experience. 


\subsection{Folklore as a Force in the Development of City, State, Region, and Nation}

A folkloristic challenge to the humanistic idea that the United States epitomizes a unified mass culture marked by the mobility of residents and a social placelessness is in its persistent, evolving regional and community traditions. With advances in communication and transportation technology in the late nineteenth century, many industrialists predicted dissipation of regional differences in favor of a national homogeneity with a standard language and lore. Some historians thought that American cultural, if not ethical, standards in the post-Civil-War era emanated from New England with its attendant Puritan values. Others believed that rapid urbanization in the late nineteenth century suggested a national cosmopolitanism that pushed out folk cultures from America's rural heartlands and embraced novelty rather than tradition. Yet another movement protested the cultural politics implied in the analogy of folk is to rural as popular is to urban. Cities, they argued, harbor distinctive expressive traditions and attachments to neighborhood cultural identities that increasingly defined the populist spirit of the United States through the twentieth century.

A major approach to America's cultural identity rooted in diverse paths of diffusion was folklorist MacEdward Leach's historico-geographic thesis that American folk cultural regions arose from colonial settlement in major eastern ports of entry (Leach 2002). He delineated "five centers of folk culture" that resulted from European colonization: New England, with Boston at the center; the New York region with New York City at the center; Pennsylvania-Delaware with Philadelphia at the center; the Tidewater South with Baltimore and Charleston at the center; and the Deep South and River country with New Orleans at the center" (Leach 2002, p. 192). In each of these places, different ethnic influences combined to form a cultural hybrid that differed from its separate Old World sources. He used the examples of localized slang and dialect that writers drew upon to create "local color" literature as evidence of attachment to folk regional identity. Folklorist Henry Glassie elaborated upon this idea by tracing the diffusion of rural folk architecture on the landscape of the eastern United States to provide evidence of the cultural significance of American regions (Glassie 1968). Although Pennsylvania constituted the last "cultural hearth" to form, he thought it was the most important because it fanned north and south, as well as west, and greatly influenced with its diverse roots of English, German, and Irish traditions the formation of the great expanse of the Midwest. He attributed the iconic American "log cabin" to German construction techniques and its rapid spread in the South and Midwest to adaptation to the wooded American landscape and the migration from Pennsylvania down into Appalachia. With regional formation, residents recognized a constellation of traditions representing distinctive identities, and often outlooks. Glassie and others suggested that southern and New England, or Yankee, social affiliations are particularly strong, and concern for folk cultural continuity and preservation are as a result also prevalent in those locations (Zelinsky 1973; Gastil 1975; Meinig 1986; Fischer 1989).

Folk cultural boundaries become less clear past the Mississippi River, but nonetheless community and regional traditions give residents what folklorists refer to as a "sense of place," or belonging to a community, in contrast to feelings of placelessness in a mass culture. To be sure, ideas of space in the vast West differed from the cultural landscapes in the East. Migration patterns changed as settlers were discouraged by the rough conditions of the arid and mountainous West (Meinig 1971; Meinig 1993). Besides the identification of a Southwest border region heavily influenced by Hispanic and Native American culture, folklorists and cultural geographers have also recognized the "Mormon Culture Region" centered in Utah and covering parts of surrounding states (Dorson 2013; Eliason 2006; Francaviglia 2013; Meinig 1965; Yorgason 2003). Its name reflects the predominant population in the area belonging to the Church of Jesus Christ of Latter-day Saints, but non-religious cultural practices have been considered as indicative of regional folklore. An example is "creative dating" involving elaborate invitations for dates and creative responses in kind. The invitations often use clever puns and other folk speech play and jokes (Eliason 2006; Young 2013). Another is the celebration of Pioneer Day on 24 July. It is an official state holiday in Utah on the occasion of the entrance of Brigham Young and his Mormon pioneers into the Salt Lake Valley in 1847. In modern day practice, the holiday observed 
inside and outside of Utah includes parades (involving the re-enactment of entering the region by handcart), rodeos, historical pageants, and fireworks displays aligning the region as the heart of the West (Eliason 1997; Olsen 1996).

Festivals showcasing local traditions are especially important in marking claims of cities, and their neighborhood communities, to distinctiveness. New Orleans's Mardi Gras festival dating at least to the eighteenth century might be best known nationally. Related to the Catholic Shrovetide practice of a public carnival, the New Orleans Mardi Gras has evolved into a multicultural tourist event that with parades and balls, and especially the "Meeting of the Courts" between the "krewes" of Rex and Comus (social clubs that work all year round to produce costumes, parades, and balls for Carnival season), represents a distinctive creolized cosmopolitan identity (Abrahams 2006; Kinser 1990; Lindahl and Ware 2011; Roberts 2006; Spitzer 2011; Stanonis 2006, pp. 170-94; Turner 2003).

Festivals do not need to be centuries old to serve this function. In Baltimore, Maryland, a grassroots movement in the Hamden section of the city created HonFest in 1994 to celebrate folk speech and image associated with the area that many writers, and civic leaders, had stigmatized. The slang term "Hon" (short for "honey"), organizers declared, is a traditional term of endearment in the working-class "Bawlmer" dialect of the city. It also epitomized a comical folk type associated with big hair, teardrop eyeglasses, and excessive cosmetics and costume jewelry. The urban festival has been a way for residents to spill into the streets and display their collective culture. Although festivals are not restricted to urban areas, in the United States, many events that involve reveling and parading, organized and spontaneous, have been associated with cities (Puglia 2015). Many traditional festivals such as New York City's annual Feast of San Gennaro (staged since 1926), known colloquially as the Little Italy Festival, and Chicago's St. Patrick's Day festival when the Chicago River turns an emerald green (begun officially in 1956), have ethnic connections and develop into citywide celebrations (Ford et al. 2008; Kennedy 2010; Malpezzi and Clements 1992, pp. 99-109). The festivals typically incorporate traditional foods, music, and games associated with the group and by extension is emblematic of the city.

The expressive genre that in folk parlance is most associated with the American city is the "urban legend." Many folklorists prefer terms such as "contemporary," "modern," or "belief" legend to indicate that the settings for, and content of, legend telling are not solely an urban phenomenon (Mullen 1972; Brunvand 1981; Bennett and Smith 1989; Ellis 1990; Tangherlini 1990; Pettit 1995; Dégh 2001; Brunvand 2004; Brunvand 2012; De Vos 2012). Yet in addition to general categorizations of this kind of legend to include cautionary stories of danger (AIDS Mary and Harry stories warning of the consequences of casual sex) and reports of strange events (a hitchhiker who mysteriously disappears and is found to be a young woman who died on the night the driver picks her up), tellers of urban legends often refer to phenomena relating anxiety over modernization that is epitomized by the city (Bennett and Smith 2007; Fine 1980). Most definitions include references to stories set in the present or recent past, and relate unusual, shocking, or mysterious occurrences, with the added feature of sounding, or having been reported, as true. More than offering a report of something that happened, many legend performances invite commentary about the story's verisimilitude and often, an implicit troubling ethical or social issue.

Although these contemporary legends have been shown to be globally diffused, many belief legends have been associated with peculiar American circumstances. Iconic is the legend of menacing alligators or mutating super-alligators overtaking New York City's dark sewers as a result of residents flushing down a toilet the animals they originally obtained as small cuddly pets (Bennett and Smith 2007; Brunvand 1981, pp. 90-98; Coleman 1979; Ingemark 2008). The story can be interpreted as a projection of anxiety about animals representing an ancient species being brought into the unnatural city. Sometimes the telling can be a commentary on the deleterious effects of tourism and the commodification of animals (cf. the "Mexican Pet" legend of a tourist in Mexico who brings home to the United States what she thinks is a small dog, but turns out to be a dying sewer rat), or symbolically associating the city with its sewers as a location of rot and danger beneath the glitzy surface (cf., belief that there are as many rats as people in 
a city, or ten cockroaches for every person) (Bennett and Smith 2007; Brunvand 1986; Mikkelson 2014). New York City as a historic, iconic city renowned for both the lights of Broadway and allure of arts as well as notorious for crime and filth is the most frequent setting for the story, although folklorists have also found similar stories told about Paris (Bennett and Smith 2007, pp. 2-3; see also (Cody 2005; Wachs 1988)). These different settings for similar plots raise questions about whether the stories arose independently or are connected as migratory, transnational narratives. In the latter case, folklorists identify the local variations as "oikotypes" (from the Greek oikos for ecology) that respond to particular environments (Abrahams 1963; Clements 1997; Cochrane 1987; Sydow 1948).

Folklorist Richard Dorson hypothesized that legends, especially more historic ones, are important in inculcating national identity in a nation-state such as the United States that had been formed relatively recently compared to the kingdoms of Europe with their ancient legacies (Dorson 1971a, pp. 94-107). He argued that while community and regional folklore roots many residents in their localities, their connection to one another across these spaces is maintained through legendry that concerns, in his words, "the special historical conditions" of the United States broadly as a nation-state. He identified themes around which nationalistic historical legends arise: colonization, westward movement, aborigines and slaves, patriotism and democracy, immigration, industrialization, and mass culture. That is not to say that the United States is unique in possessing these themes, but its frontier experience, rapidity of its immigration and industrialization during the post-Civil-War period, and revolutionary legacy combine in folklore to suggest a distinctive, even exceptional, national identity (Dorson 1971a, pp. 15-77). He cited the legend of Casey Jones, for example, as a classic heroic narrative attached to railroading and the industrial period in the United States (Dorson 1973, pp. 235-42; see also (Cohen 1973)). The image of the railroad fits the conceptualization of the United States as expansive. Further, the creation of a transcontinental railroad with a historic meeting of railroad tracks from East and West in Utah conveys a sense of its importance to nationalism, and even the folk idea of Manifest Destiny (divinely inspired for the nation to stretch as an empire from the Atlantic to the Pacific) (Dorson 1971a, pp. 35-38).

The Casey Jones legend, expressed in song as well as narrative by blacks and whites, is based on the real-life events of railroad engineer Jonathan Luther Jones (1863-1900) who early on the foggy morning of April 30, 1900, outside Canton, Mississippi, sacrificed his life for his crew and passengers by alertly grabbing for the brakes before his Cannonball Express slammed into the caboose of a stalled freight train. Headlines about his heroism and conflicting reports about the causes of the wreck and Jones's death fueled legends and songs about the incident that passed on into oral tradition. Perhaps best known is "The Ballad of Casey Jones" (Roud Folksong no. 3247) credited to African American engine-wiper Wallace Saunders who befriended Jones. Found in many variations, the song follows a familiar ballad structure with a "come all ye" opening: "Come all you rounders if you want to hear, The story of a brave engineer, Casey Jones was the rounder's name" (Dorson 1973, p. 241). Devoted to the rails, Casey Jones is immortalized with his last words: "Casey said just before he died, 'There are two more roads I would like to ride, The Northern Pacific and the Santa Fe." In addition to exemplifying devotion to duty and the quick bold thinking of the railroad engineer, the song, according to Dorson, transcends regional loyalties through the railroad and venerates the industrial future of the nation (Dorson 1973, p. 236; see also (Cohen 2000)).

One indication of the nationalist industrial symbolism that the song assumed is an often-performed parody credited to renowned labor activist Joe Hill who contributed "Casey Jones—the Union Scab." It reinterpreted the legendary events in the context of a nationwide walkout of railway employees in the Illinois Central shopmen's strike of 1911 and was sung as a union folk song for years to come:

The workers said to Casey, "Won't you help us win this strike?"

But Casey said, "Let me alone, you'd better take a hike"

Well Casey's wheezy engine ran right off the worn out track

And Casey hit the river with an awful crack. (Alderson 1942) 
The union song brings out another frequent pattern in American culture of folklore not only offering voices of unity but also cries of dissent. Folklorist John Greenway pointed out strategies for symbolically using traditional content familiar to listeners to draw attention to social protest movements (Greenway 1953). During the civil rights movement, black spirituals were used rhetorically to express powerful statements of social change. Greenway observed that in the South, union songs often changed the lyrics of gospel hymns with "I" to "We" and "God" to "CIO" (Congress of Industrial Organizations) (Greenway 1953, p. 12). Parodies of popular songs and children's rhymes frequently enter into folklore and on picket lines signs alter proverbs to show a different spin on conventional wisdom (Greenway 1953, pp. 13-19; Orr and Ohno 1981). This tradition of dissenting alteration has extended into digital communication in visual as well as verbal forms. Although social media is associated with global communication, many of the folklorized messages (also referred to as "memes") invoke nationalistic references set against digitally altered photographs of historic national icons Abraham Lincoln, George Washington, Benjamin Franklin, and more contemporary figures such as Donald Trump, Hillary Clinton, and Barack Obama (Blank 2012; Bronner 2009; Duffy et al. 2012; Oring 2014).

\subsection{Folklore as Processes in Everyday Life}

In another challenge to the prevalent "classical" textual perspective of the humanities, many American folklorists contemplating the effects of technology and modernization on tradition considered paramount the documentation of the process by which cultural expressions were produced. With the realization that people in their social interactions produce new folklore as well as invoke it in different forms-material and written as well as oral—folklorists sought to identify folklore in new realities of modern everyday life marked by technological mediation. In this theoretical perspective, individuals encounter multiple situations in the course of a day and relate to the setting and people in it with "performances" that engage folk behavior. Saying the greeting "how are you?" is standard in social encounters in the United States. It might appear routine (characterized with the folk term of "small talk"), but the responses of "hunky dory," "Just ducky (peachy, dandy)," "Fair to middling, mostly middling," "couldn't be better," "can't complain," "still among the living," "still breathing (standing, living)," "fine as a frog's hair," "fine as a frog's hair and twice as fuzzy," "not dead yet," and "old enough to know better, And you?" often ritually signal a special social connection between the speakers/texters. Further the practice contextualizes connotative meaning characteristic of a folkloric frame of action (such as reference to aging, anxiety/"troubles," lifestyle choices, medical inquiries, friendship or family relations, and insider, localized knowledge) (Coupland et al. 1992; Coupland et al. 1994; Rings 1994; Wright 1989).

People learn what kinds of performances are appropriate by understanding the different contexts or frames that contain social interaction. In line with this ethnographic shift, folklorist Dan Ben-Amos called for replacing previous definitions of folklore as oral tradition or the knowledge of semi-literate or rural isolated societies with the social interactional concept of "artistic communication in small groups" (Ben-Amos 1972). Ben-Amos's definition emphasized in keeping with an American concept of folklore the malleable, emergent nature of traditions according to the manifold social situations of daily life. Thus questions of ethnic, regional, and national folklore shifted from the characteristic genres and types within those rubrics to the situations that foster folklore and the individuals who are likely to create folklore in those frames (Paredes and Bauman [1972] 2000). In the United States, examples of such contexts that signal distinctive folk processes include college campuses, summer camps, and slumber parties.

College campuses might appear surprising as a folkloric context because students typically reside there for a short time (four years as a period that is symbolically abundant) and are involved in academic learning. ${ }^{5}$ With a lack of rites of passage from youth to adulthood in American society,

5 As discussed earlier in this essay, Roger Williams's dictionary inspired folkloristic work on Native Americans (see, for example, Heckewelder [1818] 2016), and so, too, did an early guide to college student slang produce commentaries on the 
the college experience is often viewed as a transitional status, as well as age, from childhood to adulthood. As a result, the identity of the student appears to be total, socially communitarian in dormitory complexes, and confined to a distinct landscape. The cultural challenge in this environment is often to create social bonds among students arriving from diverse backgrounds. On many campuses, the process begins with rituals that strip first-year students of their "home" identities and integrate them into campus culture. At small colleges, there may be events that pit one class against another in competition. At Hope College in Holland, Michigan, for example, the "Pull" is a tug-of-war between first and second-year students, tugging a six-hundred-foot, twelve-hundred-pound hawser rope. The experience encourages bonding with one's class and engagement in a task collaboratively. Students learn slang and customs of the campus that they associate with a cultural identity. The social relationships might lead to sharing of legends typical of college students nationwide about anxieties of coming of age, including sexual choices, effects of drugs and alcohol, and dealing independently with authority (Bronner 2012a, pp. 142-44).

With more than 12,000 day and resident camps attended by over eleven million children in the United States, the summer camp is a frequent context for folkloric performances before students get to college (Mechling 1999). Often emphasizing an experience with nature as a reaction to modern technology and urbanization, the camps frequently have legends of a bogey-man kind of figure lurking in the woods. The name and origin of the figure vary; it might include ghosts of Native American chiefs because of the association with the first inhabitants of the woods, monstrous chimerical animals, or deranged hulking men. The process of creation appears similar in this context; tellers caution listeners to stay out of the woods or surroundings or else this figure will take them away. The cautionary tales have an obvious connection to "boogie-men" who lurk in the dark and serve to keep children from straying away from home. The stories of camp are more elaborate but serve similar functions of social control (Leary 1973; Widdowson 1977; Green 1980; Ellis 1982; Furst 1998).

The slumber party is often considered a special American context appealing to preteen and adolescent girls. Attendees spend the night at a host's house with minimal parental intervention. Typical events in this social frame are legendary exchanges and participation in supernatural rituals or games. Although younger children are thought to be more "superstitious" because of a lack of rational awareness, older youths usually engage in folk magical practices and show interest in ghosts and supernatural phenomena. Folklorists have theorized that these practices result from questioning during adolescence of the boundaries between life and death (Freed 1993; Tucker 1984; Tucker 2005). Adolescents feel invulnerable and vulnerable at the same time and their awareness of death, despite possessing youthful vitality, is apparent. They became aware of teen suicide and use narratives to question motivations for such extreme responses to stress. At parties they might summon the dead through the use of Ouija boards and séances (Bronner 1988, pp. 166-67; Freed 1993; Ellis 2000, pp. 62-86; Ellis 2004, pp. 174-96). They might also test their youthful powers by levitating their friends, often with the chant "light as a feather, stiff as a board" (Tucker 1984; Tucker 2007b). Performances of modern legends about bizarre occurrences frequently conclude with invitations to listeners to comment and discuss through the folkloric frame their veracity and the age-related issues of being alone and independent, dealing with mortal danger, and engaging in sex (Brunvand 1993, pp. 109-12; Fine 1992; Greenberg 1973; Whatley and Henken 2000).

A context that emerges after youth begin driving automobiles is "legend trips" to verify supernatural legends, often in isolated locations. A frequent phenomenon to test is of "gravity hills" that push a car upward even though the brake is on (Baker 1982, p. 200; Lindahl 2005). They might go as a group to settings of "spook lights" and creepy cemeteries to dare one another to overcome their fears (Bird 1994; Ellis 1989; Ellis 1996; Meley 1990; Prizer 2004; Tucker 2007a, pp. 182-210). In the

folklore of students as a special folk group: Benjamin Homer Hall, A Collection of College Words and Customs, originally published in 1856 (see Hall [1856] 1968). (1856 rpt., Detroit: Gale, 1968). See also (Dorson 1949; Baker 1983; Toelken 1986; Tucker 2007a; Tucker 2008). 
digital era, youths take videos of their adventures and post them for others to comment on the core of belief (Kinsella 2014; Tucker 2011; Tucker 2012). They engage in telling what folklorists call "personal narratives" that relate individual experiences within American structural and stylistic expectations of the "good story." Often events that spark the personal narrative as a folkloric frame are family sagas, workplace dramas, scary situations, social faux pas, supernatural or miraculous experiences ("memorates" in folkloristic terminology), and sexual encounters (Boatright 1958; Braid 1996; De Caro 2013; Dégh and Vázsonyi 1974; Fine 1987; Honko 1964; Pentikainen 1973; Robinson 1981; Sebba-Elran 2003; Stahl 1977; Sweterlitsch 1996; Tucker 1992; Wilson 1991; Zeitlin et al. 1982).

Because much of digital communication in the twenty-first century is not "face to face interaction" characteristic of what analog folklorists referred to as a performative frame of folklore, many analysts reserved performance analysis for communication of verbal art in small group situations, and referred more broadly to folk practices to cover the kinds of expressive processes that could be called traditional (Bronner 2016, 2017). The folkloristic finding was that the Internet as a symbol of mass culture does not displace folk culture. Instead, as a user-driven medium it provided new platforms for folkloric exchange and in many cases mediation of traditional knowledge into social networks rather than face-to-face groups. These platforms are often assumed to be global in reach, but they often make use of traditional knowledge and social conduits that are concentrated in the United States. In addition to finding unique manifestations of folk behavior in cyber-environments such as hackers injecting legendary characters (e.g., "The White Lady of Perion" in MapleStory video games based upon "White Lady" lovers' lane legends), "creepypastas" and collective creations (horror-related legends posted around the Internet such as the Slender Man and Ted the Caver), virus hoaxes ( e.g., Goodtimes, Dance of the Pope, and An Internet Flower for You), viral "memes" (Grumpy Cat, U Mad Bro, But That's None of My Business), the comparative microfunctions of communicative topics in analog and digital culture provide material for analysis of joking, legend tripping, and ritualizing off- and on-line (Frank 2011; Kinsella 2014; Ellis 2012; Blank 2013; Boyer 2013; Chess and Newsom 2015; Peck 2015; Henriksen 2016). With these expressions in mind, a revised definition of folklore emerged to cover analog and digital as well as historic and contemporary culture of "traditional knowledge put into, and drawing from, practice" (Bronner 2016).

Knowledge or lore is perceived or constructed as traditional, characteristically through its repetition and variation, and connotative evocation of precedent. It can be viewed as distinct from, although, sometimes integrated into, the notion of popular culture as fixed in form and commercialized (folklore can also be "popular" and broad-based beyond the small group or subculture). Reference to the actions of "put into and drawing from" suggests the framing of connotative, purposeful enactments as an adaptation from precedent or an outcome of repeatable behavior. This outcome can be material and social as well as verbal. It can be constructed by and enacted for the individual. Popularly, folklore in the United States can be rhetorically used to refer to the verisimilitude, and significance, of cultural knowledge in an uncertain, individualistic world. Indeed, a folklore-centered humanities breaks down divisions between high and low, local and global, and individual and society. Continuing to challenge versions of the humanities in classical terms, folklore refers to the expressions of this knowledge in story, song, speech, custom, and craft as meaningful for what it conveys and enacts about tradition in a future-oriented society. That tradition in the United States is old and new, national and regional, transnational and ethnic, persistent and vanishing, continuous and changing, special and everyday, and always expressive and connotative.

Conflicts of Interest: The author declares no conflict of interest.

\section{References}

Abrahams, Roger D. 1963. Folklore in Culture: Notes Toward an Analytic Method. Texas Studies in Literature and Language 5: 98-110. 
Abrahams, Roger D. 1970. Deep Down in the Jungle: Negro Narrative Folklore form the Streets of Philadelphia. Chicago: Aldine.

Abrahams, Roger D. 1988. Rough Sincerities: William Wells Newell and the Discovery of Folklore in Late-19th Century America. In Folk Roots, New Roots: Folklore in American Life. Edited by Jane S. Becker and Barbara Franco. Lexington: Museum of Our National Heritage, pp. 61-76.

Abrahams, Roger D. 2006. Blues for New Orleans: Mardi Gras and America's Creole Soul. Philadelphia: University of Pennsylvania Press.

Alexander, Hartley B. 1933. Francis La Flesche. American Anthropologist 35: 328-31. [CrossRef]

Alexander, Hartley B. 1982. Francis La Flesche: The American Indian as Anthropologist. Isis 73: 497-510. [CrossRef]

Backus, Emma. 1898. Animal Tales from North Carolina. Journal of American Folklore 11: 284-91. [CrossRef]

Bascom, William. 1981. African Folktales in America: XI. Taught an Incriminating Song (Saying). Research in African Literatures 12: 203-13.

Baer, Florence E. 1980. Sources and Analogues of the Uncle Remus Tales. Helsinki: Suomalainen Tiedeakatemia.

Baker, Ronald L. 1982. Hoosier Folk Legends. Bloomington: Indiana University Press.

Baker, Ronald L. 1983. The Folklore of Students. In Handbook of American Folklore. Edited by Richard M. Dorson. Bloomington: Indiana University Press, pp. 106-14.

Baughman, Ernest W., and Clayton A. Holaday. 1944. Tall Tales and 'Sells' from Indiana University Students. Hoosier Folklore Bulletin 3: 59-71.

Bell, Michael J. 1973. William Wells Newell and the Foundation of American Folklore Scholarship. Journal of the Folklore Institute 10: 7-21. [CrossRef]

Ben-Amos, Dan. 1972. Toward a Definition of Folklore in Context. In Toward New Perspectives in Folklore. Edited by Richard M. Bauman and Américo Paredes. Austin: University of Texas Press, pp. 3-15.

Bennett, Gillian, and Paul Smith. 1989. Introduction: The Birth of Contemporary Legend. In The Questing Beast: Perspectives on Contemporary Legend. Edited by Gillian Bennett and Paul Smith. Sheffield, UK: Sheffield Academic Press, pp. 13-26.

Bennett, Gillian, and Paul Smith, eds. 2007. Urban Legends: A Collection of International Tall Tales and Terrors. Westport: Greenwood Press.

Bickley, R. Bruce, ed. 1981. Critical Essays on Joel Chandler Harris. Boston: G. K. Hall.

Bickley, R. Bruce. 1987. Joel Chandler Harris: A Biography and Critical Study. Athens: University of Georgia Press.

Bickley, R. Bruce, and Hugh T. Keenan. 1997. Joel Chandler Harris: An Annotated Bibliography of Criticism, 1977-1996. Westport: Greenwood Press.

Biebuyck-Goetz, Brunhilde. 1977. “This is the Dyin' Truth": Mechanisms of Lying. Journal of the Folklore Institute 14: 73-95. [CrossRef]

Bird, S. Elizabeth. 1994. Playing with Fear: Interpreting the Adolescent Legend Trip. Western Folklore 53: 191-209. [CrossRef]

Black Elk, Nicholas. As told through John G. Neihardt. 1988. Black Elk Speaks: Being the Life Story of a Holy Man of the Oglala Sioux. Lincoln: University of Nebraska Press. First published 1932.

Blair, Walter. 1944. Tall Tale America: A Legendary History of Our Humorous Heroes. New York: Coward-McCann.

Blank, Trevor J. 2012. Introduction: Pattern in the Virtual Folk Culture of Computer-Mediated Communication. In Folk Culture in the Digital Age: The Emergent Dynamics of Human Interaction. Edited by Trevor J. Blank. Logan: Utah State University Press, pp. 8-11.

Blank, Trevor J. 2013. The Last Laugh: Folk Humor, Celebrity Culture, and Mass-Mediated Disasters in the Digital Age. Madison: University of Wisconsin Press.

Boas, Franz. 1915. Mythology and Folk-Tales of the North American Indians. In Anthropology in North America. Edited by Franz Boas. New York: G.E. Stechert, pp. 306-49.

Boas, Franz. 1938. Mythology and Folklore. In General Anthropology. Edited by Franz Boas. New York: D.C. Heath, pp. 609-26.

Boatright, Mody. 1945. Gib Morgan: Minstrel of the Oil Fields. Denton: University of North Texas Press.

Boatright, Mody. 1958. The Family Saga and Other Phases of American Folklore. Urbana: University of Illinois Press. Boorstin, Daniel J. 1956. The Place of Thought in American Life. American Scholar 25: 137-50.

Boyer, Tina Marie. 2013. The Anatomy of a Monster: The Case of Slender Man. Preternature 2: 240-61.

Brady, Margaret K. 1984. Some Kind of Power: Navajo Children's Skinwalker Narratives. Salt Lake City: University of Utah Press. 
Braid, Donald. 1996. Personal Narrative and Experiential Meaning. Journal of American Folklore 109: 5-30. [CrossRef] Brandes, Stanley. 1985. Forty: The Age and the Symbol. Knoxville: University of Tennessee Press.

Brasch, Walter M. 2000. Brer Rabbit, Uncle Remus, and the "Cornfield Journalist": The Tale of Joel Chandler Harris. Macon: Mercer University Press.

Bremer, Richard G. 1987. Indian Agent and Wilderness Scholar: The Life of Henry Rowe Schoolcraft. Mount Pleasant: Clarke Historical library, Central Michigan University.

Brendle, Thomas R., and William S. Troxell. 1944. Pennsylvania German Folk Tales, Legends, Once-Upon-a-Time Stories, Maxims and Sayings Spoken in the Dialect Popularly Known as Pennsylvania Dutch. Norristown: Pennsylvania German Society.

Bronner, Simon J. 1986. American Folklore Studies: An Intellectual History. Lawrence: University Press of Kansas.

Bronner, Simon J. 1988. American Children's Folklore. Little Rock: August House.

Bronner, Simon J. 1996. Popularizing Pennsylvania: Henry W. Shoemaker and the Progressive Uses of Folklore and History. University Park: Pennsylvania State University Press.

Bronner, Simon J. 2002. Folk Nation: Folklore in the Creation of American Tradition. Lanham: Rowman \& Littlefield.

Bronner, Simon J. 2006. Toasts and Dozens. In Encyclopedia of American Folklife. Edited by Simon J. Bronner. Armonk: M.E. Sharpe, pp. 1293-96.

Bronner, Simon J. 2007. The Analytics of Alan Dundes. In The Meaning of Folklore. Edited by Simon J. Bronner. Logan: Utah State University Press, pp. 1-50.

Bronner, Simon J. 2009. Digitizing and Virtualizing Folklore. In Folklore and the Internet: Vernacular Expression in a Digital World. Edited by Trevor J. Blank. Logan: Utah State University Press, pp. 21-66.

Bronner, Simon J. 2012a. Campus Traditions: Folklore from the Old-time College to the Modern Mega-University. Jackson: University Press of Mississippi.

Bronner, Simon J. 2012b. 'Sort of a Hero': Jack Fasig and the Strongman Theme in American Legendry. Contemporary Legend 2: 1-26.

Bronner, Simon J. 2013. Fakelore, Folklorism, and Intangible Heritage. In Encyclopedia of Local History, 3rd ed. Edited by Amy H. Wilson. Lanham: Rowman \& Littlefield, pp. 222-23.

Bronner, Simon J. 2016. Toward a Definition of Folklore in Practice. Cultural Analysis 15: 6-27.

Bronner, Simon J. 2017. Folklore: The Basics. New York: Routledge.

Brookes, Stella Brewer. 1950. Joel Chandler Harris: Folklorist. Athens: University of Georgia Press.

Brown, Cecil. 2003. Stagolee Shot Billy. Cambridge: Harvard University Press.

Brown, Waln K. 1974. Cultural Learning through Game Structure: A Study of Pennsylvania German Children's Games. Pennsylvania Folklife 23: 2-11.

Brownell, Charles De Wolf. 1864. The Indian Races of North and South America. Hartford: Hurlbut, Scranton.

Browner, Tara. 2002. Heartbeat of the People: Music and Dance of the Northern Pow-Wow. Urbana: University of Illinois Press.

Brunvand, Jan Harold. 1981. The Vanishing Hitchhiker: American Urban Legends and Their Meanings. New York: W.W. Norton. Brunvand, Jan Harold. 1986. The Mexican Pet: More "New" Urban Legends and Some Old Favorites. New York: W. W. Norton. Brunvand, Jan Harold. 1993. The Baby Train and Other Lusty Urban Legends. New York: W.W. Norton.

Brunvand, Jan Harold. 2004. The Vanishing 'Urban Legend'. Midwestern Folklore 30: 5-20.

Brunvand, Jan Harold. 2012. Encyclopedia of Urban Legends, updated and expanded ed. Santa Barbara: ABC-CLIO. Bryant, Jerry H. 2003. Born in a Mighty Bad Land: The Violent Man in African American Folklore and Fiction. Bloomington: Indiana University Press.

Buffington, Albert F. 1974. Pennsylvania German Secular Folksongs. Breinigsville: Pennsylvania German Society. Bynum, Joyce. 1988. Tall Tales: Part II Famous Tellers of Tall Tales. ETC: A Review of General Semantics 45: 186-89. Castaneda, Carlos. 1968. The Teachings of Don Juan: A Yaqui Way of Knowledge. Berkeley: University of California Press. Chase, Richard. 1943. The Jack Tales. Boston: Houghton Mifflin.

Chase, Richard. 1950. Jack and the Three Sillies. Boston: Houghton Mifflin.

Chase, Richard, comp. 1955. The Complete Tales of Uncle Remus. Boston: Houghton Mifflin.

Chess, Shira, and Eric Newsom. 2015. Folklore, Horror Stories, and the Slender Man: The Development of an Internet Mythology. New York: Palgrave Macmillan.

Child, Francis James. 1965. The English and Scottish Popular Ballads. 5 vols. New York: Dover. First published 1882-1898.

Clements, William M. 1996. Native American Verbal Art: Texts and Contexts. Tucson: University of Arizona Press. 
Clements, William M. 1997. Oikotype/Oicotype. In Folklore: An Encyclopedia of Beliefs, Customs, Tales, Music, and Art. 2 vols. Edited by Thomas A. Green. Santa Barbara: ABC-CLIO, vol. 2, pp. 604-5.

Cline, Ruth I. 1930. The Tar-Baby Story. American Literature 2: 72-78. [CrossRef]

Clough, Ben C. 1947. The American Imagination at Work: Tall Tales and Folk Tales. New York: Knopf.

Cocchiara, Giuseppe. 1971. The History of Folklore in Europe. Translated by John N. McDaniel. Philadelphia: Institute for the Study of Human Issues.

Cochrane, Timothy. 1987. The Concept of Ecotypes in American Folklore. Journal of Folklore Research 24: 33-55.

Cody, Cornelia. 2005. 'Only in New York': The New York City Personal Experience Narrative. Journal of Folklore Research 42: 217-44. [CrossRef]

Coffin, Tristram Potter. 1977. The British Traditional Ballad in North America, rev. ed. Austin: University of Texas Press. Cohen, Norm. 1973. 'Casey Jones': At the Crossroads of Two Ballad Traditions. Western Folklore 32: 77-103. [CrossRef] Cohen, Norm. 2000. Long Steel Rail: The Railroad in American Folksong. Urbana: University of Illinois Press.

Coleman, Loren. 1979. Alligators-in-the-Sewers: A Journalistic Origin. Journal of American Folklore 92: 335-38. [CrossRef]

Coupland, Justine, Nikolas Coupland, and Jeffrey D. Robinson. 1992. “How Are You?”: Negotiating Phatic Communion. Language in Society 21: 207-30. [CrossRef]

Coupland, Justine, Jeffrey D. Robinson, and Nikolas Coupland. 1994. Frame Negotiation in Doctor-Elderly Patient Consultations. Discourse \& Society 5: 89-124.

Culin, Stewart. 1890. Customs of the Chinese in America. Journal of American Folklore 3: 195-97. [CrossRef]

Culin, Stewart. 1891. The Gambling Games of the Chinese in America. Philadelphia: University of Pennsylvania Press.

Cunningham, Keith. 1992. American Indians' Kitchen-Table Stories: Contemporary Conversations with Cherokee, Sioux, Hopi, Osage, Navajo, Zuni, and Members of Other Nations. Little Rock: August House.

Cusick, David. 2006. David Cusick's Sketches of Ancient History of the Six Nations (1828). Available online: https: / / digitalcommons.unl.edu/cgi/viewcontent.cgi?article=1027\&context=libraryscience (accessed on 15 February 2018).

Darnell, Regna. 1973. American Anthropology and the Development of Folklore Scholarship-1890-1920. Journal of the Folklore Institute 10: 23-39. [CrossRef]

Davis, Donald. 1992. Southern Jack Tales. Little Rock: August House.

Davis, Rose M. 1957. How Indian is Hiawatha? Midwest Folklore 7: 5-25.

De Caro, Frank, ed. 2009. An Anthology of American Folktales and Legends. Armonk: M.E. Sharpe.

De Caro, Frank. 2013. Stories of Our Lives: Memory, History, Narrative. Logan: Utah State University Press.

Dégh, Linda. 2001. Legend and Belief. Bloomington: Indiana University Press.

Dégh, Linda, and Andrew Vázsonyi. 1974. The Memorate and the Proto-Memorate. Journal of American Folklore 87: 225-39. [CrossRef]

De Vos, Gail. 2012. What Happens Next? Contemporary Urban Legends and Popular Culture. Santa Barbara: ABC-CLIO.

DeMallie, Raymond J. 1993. 'These Have No Ears': Narrative and the Ethnohistorical Method. Ethnohistory 40: 515-38. [CrossRef]

Dixon, E. James. 1993. Quest for the Origins of the First Americans. Albuquerque: University of New Mexico Press.

Dobie, J. Frank. 1931. Coronado's Children: Tales of Lost Mines and Buried Treasures of the Southwest. New York: Literary Guild of America.

Dorson, Richard M. 1939. Davy Crockett, American Comic Legend. New York: Spiral Press.

Dorson, Richard M. 1942. Davy Crockett and the Heroic Age. Southern Folklore Quarterly 6: 95-102.

Dorson, Richard M. 1949. The Folklore of Colleges. American Mercury 68: 671-77.

Dorson, Richard M. 1971a. American Folklore and the Historian. Chicago: University of Chicago Press.

Dorson, Richard M. 1971b. How Shall We Rewrite Charles M. Skinner Today? In American Folk Legend. Edited by Wayland D. Hand. Berkeley: University of California Press, pp. 69-95.

Dorson, Richard M. 1973. America in Legend: Folklore from the Colonial Period to the Present. New York: Pantheon.

Dorson, Richard M. 1976. Folklore and Fakelore: Essays Toward a Discipline of Folk Studies. Cambridge: Harvard University Press.

Dorson, Richard M. 1977. American Folklore, rev. ed. Chicago: University of Chicago Press.

Dorson, Richard M. 1982. Man and Beast in American Comic Legend. Bloomington: Indiana University Press.

Dorson, Richard M. 2013. Utah Mormons. In Latter-Day Lore: Mormon Folklore Studies. Edited by Eric A. Eliason. and Tom Mould. Salt Lake City: University of Utah Press, pp. 37-42. 
Dorson, Richard M. 2015. American Negro Folktales. New York: Dover. First published 1967.

Duffy, Margaret, Janis Teruggi Page, and Rachel Young. 2012. Obama as Anti-American: Visual Folklore in Right-Wing Forwarded E-mails and Construction of Conservative Social Identity. Journal of American Folklore 125: 177-203. [CrossRef]

Dugaw, Dianne, ed. 1995. The Anglo-American Ballad: A Folklore casebook. New York: Garland.

Dundes, Alan. 1964. Robert Lee J. Vance: American Folklore Surveyor of the 1890's. Western Folklore 23: 27-34. [CrossRef]

Dundes, Alan. 1966. The American Concept of Folklore. Journal of the Folklore Institute 3: 226-49. [CrossRef]

Dundes, Alan. 1980. Interpreting Folklore. Bloomington: Indiana University Press.

Dundes, Alan. 2007. Folk Ideas as Units of Worldview. In The Meaning of Folklore: The Analytic Essays of Alan Dundes. Edited by Simon J. Bronner. Logan: Utah State University Press, pp. 183-95.

Dundes, Alan, and Carl R. Pagter. 1978. Work Hard and You Shall Be Rewarded: Urban Folklore from the Paperwork Empire. Bloomington: Indiana University Press.

Eliason, Eric A. 1997. Pioneers and Recapitulation in Mormon Popular Historical Expression. In Usable Pasts: Traditions and Group Expressions in North America. Edited by Tad. Tuleja. Logan: Utah State University Press, pp. 175-212.

Eliason, Eric A. 2006. Mormon Culture Region. In Encyclopedia of American Folklife. Edited by Simon J. Bronner. Armonk, NY: M.E. Sharpe, pp. 868-71.

Ellis, Bill. 1982. 'Ralph and Rudy': The Audience's Role in Recreating a Camp Legend. Western Folklore 41: 169-91. [CrossRef]

Ellis, Bill. 1989. Death by Folklore: Ostension, Contemporary Legend, and Murder. Western Folklore 48: 201-20. [CrossRef]

Ellis, Bill. 1990. Introduction: Contemporary Legends in Emergence. Western Folklore 49: 1-7. [CrossRef]

Ellis, Bill. 1996. Legend Trip. In American Folklore: An Encyclopedia. Edited by Jan Harold. Brunvand. New York: Garland, pp. 439-40.

Ellis, Bill. 2000. Raising the Devil: Satanism, New Religions, and the Media. Lexington: University Press of Kentucky. Ellis, Bill. 2004. Lucifer Ascending: The Occult in Folklore and Popular Culture. Lexington: University Press of Kentucky.

Ellis, Bill. 2012. The E-Mail Virus Panic. In The Martians Have Landed!: A History of Media-Driven Panics and Hoaxes. Edited by Robert E. Bartholomew and Benjamin Radford. Jefferson: McFarland, pp. 123-26.

Espinosa, Aurelio M. 1943. A New Classification of the Fundamental Elements of the Tar-Baby Story on the Basis of Two Hundred and Sixty-Seven Versions. Journal of American Folklore 56: 31-37. [CrossRef]

Evans, Robley. 1996. George Bird Grinnell. Boise: Boise State University Western Writers Series.

Fife, Austin E., and Francesca Redden. 1954. The Pseudo-Indian Folksongs of the Anglo-American and French-Canadian. Journal of American Folklore 67: 379-94. [CrossRef]

Fine, Gary Alan. 1980. The Kentucky Fried Rat: Legends and Modern Society. Journal of the Folklore Institute 17: 222-43. [CrossRef]

Fine, Gary Alan. 1987. Community and Boundary: Personal Experience Stories of Mushroom Collectors. Journal of Folklore Research 24: 223-40.

Fine, Gary Alan. 1992. Manufacturing Tales: Sex and Money in Contemporary Legends. Knoxville: University of Tennessee Press.

Fischer, David Hackett. 1989. Albion's Seed: Four British Folkways in America. New York: Oxford University Press.

Fishwick, Marshall W. 1959. Sons of Paul: Folklore or Fakelore? Western Folklore 18: 277-86. [CrossRef]

Fleming, E. McClung. 1965. The American Image as Indian Princess, 1765-1783. Winterthur Portfolio 2: 65-81. [CrossRef]

Fleming, E. McClung. 1967. From Indian Princess to Greek Goddess: The American Image, 1783-1815. Winterthur Portfolio 3: 37-66. [CrossRef]

Fletcher, Alice C., and Francis La Flesche. 1911. The Omaha Tribe. Washington, D.C.: Bureau of American Ethnology, Smithsonian Institution.

Ford, Larry, Florinda Klevisser, and Francesca Carli. 2008. Ethnic Neighborhoods and Urban Revitalization: Can Europe Use the American Model? Geographical Review 98: 82-102. [CrossRef]

Foster, George M. 1964. Treasure Tales, and the Image of the Static Economy in a Mexican Peasant Community. Journal of American Folklore 77: 39-44. [CrossRef] 
Fox, William S. 1980. Folklore and Fakelore: Some Sociological Considerations. Journal of the Folklore Institute 17: 244-61. [CrossRef]

Francis, David A. 2016. Sunrise at Sipayik: A Passamaquoddy Tribal and Personal Oral History: As Told by David A. Francis (1917-2016) to Karen Schaumann. Orono: Maine Folklife Center.

Francaviglia, Richard V. 2013. The Mormon Landscape: Definition of an Image in the American West. In Latter-Day Lore: Mormon Folklore Studies. Edited by Eric A. Eliason and Tom Mould. Salt Lake City: University of Utah Press, pp. 43-47.

Frank, Russell. 2011. Newslore: Contemporary Folklore on the Internet. Jackson: University Press of Mississippi.

Freed, Shaari. 1993. Spooky Activities and Group Loyalty. Children's Folklore Review 16: 33-40.

Furst, Hugo. 1998. The Legend of Cropsey: A Legacy of Terror at Summer Camp. New Rochelle: Full Moon Books.

Gastil, Raymond D. 1975. Cultural Regions of the United States. Seattle: University of Washington Press.

Gerstle, Gary. 1999. Theodore Roosevelt and the Divided Character of American Nationalism. Journal of American History 86: 1280-307. [CrossRef]

Gilley, Jennifer, and Stephen Burnett. 1998. Deconstructing and Reconstructing Pittsburgh's Man of Steel: Reading Joe Magarac against the Context of the $20^{\text {th }}$-Century Steel Industry. Journal of American Folklore 111: 392-408. [CrossRef]

Glassie, Henry. 1968. Pattern in the Material Folk Culture of the Eastern United States. Philadelphia: University of Pennsylvania Press.

Granger, Byrd H. 1977. A Motif Index for Lost Mines and Treasures Applied to Redaction of Arizona Legends, and to Lost Mine and Treasure Legends Exterior to Arizona. Tucson: University of Arizona Press.

Green, A. E. 1980. Some Thoughts on Threatening Children. In Folklore Studies in Honour of Herbert Halpert: A Festschrift. Edited by Kenneth S. Goldstein and Neil V. Rosenberg. St. John's Newfoundland: Memorial University of Newfoundland, pp. 187-210.

Green, Rayna D. 1975. Traits of Indian Character: The 'Indian' Anecdote in American Vernacular Tradition. Southern Folklore Quarterly 39: 233-62.

Green, Rayna D. 1996. 'We Ever Saw These Things Before: Southwest Indian Laughter and Resistance to the Invasion of the Tse Va Ho. In The Great Southwest of the Fred Harvey Company and the Santa Fe Railway. Edited by Marta Weigle and Barbara Babcock. Tucson: University of Arizona Press, pp. 201-6.

Greenberg, Andrea. 1973. Drugged and Seduced: A Contemporary Legend. New York Folklore Quarterly 29: 131-58. Greenway, John. 1953. American Folksongs of Protest. New York: A.S. Barnes.

Grinnell, George Bird. 1961. Pawnee Hero Stories and Folk-Tales. Lincoln: University of Nebraska Press, First published 1889. Hale, Horatio. 1881. Hiawatha and the Iroquois Confederation: A Study in Anthropology. Salem: Salem Press.

Haley, Gail E. 1992. Mountain Jack Tales. New York: Dutton.

Hall, Benjamin Homer. 1968. A Collection of College Words and Customs. Detroit: Gale. First published 1968.

Heckewelder, John. 2016. History, Manners, and Customs of the Indian Nations Who Once Inhabited Pennsylvania and the Neighboring States. University Park, PA: Metalmark Books. First published 1818.

Henriksen, Line. 2016. A Short Bestiary of Creatures from the Web. In The Ashgate Research Companion to Paranormal Cultures. Edited by Olu Jenzen and Sally R. Munt. New York: Routledge, pp. 405-16.

Honko, Lauri. 1964. Memorates and the Study of Folk Beliefs. Journal of the Folklore Institute 1: 5-19. [CrossRef]

Honko, Lauri, ed. 2000. Textualization of Oral Epics. Berlin: Mouton de Gruyter.

Ingemark, Camilla Asplund. 2008. The Octopus in the Sewers: An Ancient Legend Analogue. Journal of Folklore Research 45: 145-70. [CrossRef]

Isbell, Robert. 1996. The Last Chivaree: The Hicks Family of Beech Mountain. Chapel Hill: University of North Carolina Press.

Ives, Ronald L. 1956. An Early Speculation Concerning the Asiatic Origin of the American Indian. American Antiquity 31: 420-21. [CrossRef]

Jackson, Bruce. 1974. "Get Your Ass in the Water and Swim Like Me": Narrative Poetry from Black Oral Tradition. Cambridge: Harvard University Press.

Jackson, Jason Baird. 2003. Yuchi Ceremonial Life: Performance, Meaning, and Tradition in a Contemporary American Indian Community. Lincoln: University of Nebraska Press.

Jones, Bessie, and Bess Lomax Hawes. 1972. Step It Down: Games, Plays, Songs, and Stories from the Afro-American Heritage. New York: Harper \& Row. 
Jones, Michael Owen. 1987. A Feeling for Form, as Illustrated by People at Work. In Exploring Folk Art: Twenty Years of Thought on Craft, Work, and Aesthetics by Michael Owen Jones. Ann Arbor: UMI Research Press, pp. 119-32.

Junquera, Imelda Martin. 2005. From Black Elk Speaks to Lakota Woman: Reflections upon Modern Collaborative Native American Autobiography. Litteraria Pragensia: Studies in Literature and Culture 15: 58-64.

Kahn, Ed. 1960. Tall-Tale Lying Contest. Western Folklore 19: 134-35.

Kalter, Susan. 2002. Finding a Place for David Cusick in Native American Literary History. MELUS 27: 9-42. [CrossRef]

Kareem, Sarah Tindal. 2012. Fictions, Lies, and Baron Munchausen's Narrative. Modern Philology 109: 483-509. [CrossRef]

Kennedy, Bridget Houlihan. 2010. Chicago's South Side Irish Parade. Charleston: Arcadia.

Kennedy, James. 1856. On the Probable Origin of the American Indians, with Particular Reference to that of the Caribs. Journal of the Ethnological Society of London 4: 226-67. [CrossRef]

Kinsella, Michael. 2014. Legend-Tripping Online: Supernatural Folklore and the Search for Ong's Hat. Jackson: University Press of Mississippi.

Kinser, Samuel. 1990. Carnival, American Style: Mardi Gras at New Orleans and Mobile. Chicago: University of Chicago Press.

Kroeber, Theodora. 1961. Ishi in Two Worlds: A Biography of the Last Wild Indian in North America. Berkeley: University of California Press.

La Flesche, Francis. 1905. Who Was the Medicine Man? Journal of American Folklore 18: 269-75. [CrossRef]

La Flesche, Francis. 2013. Foreword. In Life Among the Indians: First Fieldwork among the Sioux and Omahas. Edited by Joanna C. Scherer and Raymond J. DeMallie. Lincoln: University of Nebraska Press, pp. 83-100.

Laughlin, William S. 1977. Origins and Affinities of the First Americans. Current Anthropology 18: 526-28. [CrossRef] Laws, G. Malcolm, Jr. 1957. American Balladry from British Broadsides. Philadelphia: American Folklore Society.

Laws, G. Malcolm, Jr. 1964. Native American Balladry: A Descriptive Study and a Bibliographical Syllabus. Philadelphia: American Folklore Society.

Leach, MacEdward. 2002. Folklore and American Regionalism. In Folk Nation: Folklore in the Creation of American Tradition. Edited by Simon J. Bronner. Wilmington, DE: SR Books, pp. 189-98.

Leary, James P. 1973. The Boondocks Monster of Camp Wapehani. Indiana Folklore 6: 174-90.

Light, Kathleen. 1975. Uncle Remus and the Folklorists. Southern Literary Journal 7: 88-104.

Lindahl, Carl. 2004. The Nation's Most Celebrated Storytelling Family: The Hickses and the Harmons. In American Folktales from the Collections of the Library of Congress. Edited by Carl. Lindahl. Armonk: M.E. Sharpe, pp. 1-58.

Lindahl, Carl. 2005. Ostensive Healing: Pilgrimage to the San Antonio Ghost Tracks. Journal of American Folklore 118: 164-85. [CrossRef]

Lindahl, Carl, and Carolyn Ware. 2011. Cajun Mardi Gras Masks. Jackson: University Press of Mississippi.

Lomax, John A. 1934. Cowboy Songs and Other Frontier Ballads. New York: Macmillan.

Lomax, John A, and Alan Lomax. 1941. Our Singing Country: A Second Volume of American Ballads and Folk Songs. New York: Macmillan.

Loomis, C. Grant. 1945. The American Tall Tale and the Miraculous. California Folklore Quarterly 4: 109-28. [CrossRef]

MacCurdy, George Grant. 1915. Race in the Pacific Area, with Special Reference to the Origin of the American Indians: Antiquity of Occupation. American Anthropologist 17: 708-11. [CrossRef]

Malpezzi, Frances M., and William M. Clements. 1992. Italian-American Folklore. Little Rock: August House.

Marsh, Moira. 2015. Practically Joking. Logan: Utah State University Press.

Martinez, Michael, Jaqueline Hurtado, CNN, and CNN en Espanol. 2015. 'Narcocorridos': El Chapo's Jailbreak Inspires. New Round of Folk Songs. CNN, July 25. Available online: http:/ /www.cnn.com/2015/07/25/us/ el-chapo-escape-narcocorridos/ (accessed on 9 June 2016).

McCarthy, William Bernard, ed. 1994. Jack in Two Worlds: Contemporary North American Tales and Their Tellers. Chapel Hill: University of North Carolina Press.

McCarthy, William Bernard, ed. 2007. Cinderella in America: A Book of Folk and Fairy Tales. Jackson: University Press of Mississippi.

McDowell, John H. 2012. The Ballad of Narcomexico. Journal of Folklore Research 49: 249-74. [CrossRef]

Mechling, Jay. 1999. Children's Folklore in Residential Institutions: Summer Camps, Boarding Schools, Hospitals, and Custodial Facilities. In Children's Folklore: A Source Book. Edited by Brian Sutton-Smith, Jay Mechling, Thomas W. Johnson and Felicia R. McMahon. Logan: Utah State University Press, pp. 273-92. 
Mechling, Jay. 2001. On My Honor: Boy Scouts and the Making of American Youth. Chicago: University of Chicago Press.

Meinig, D. W. 1965. The Mormon Culture Region: Strategies and Patterns in the Geography of the American West, 1847-1964. Annals of the Association of American Geographers 55: 191-220. [CrossRef]

Meinig, D. W. 1971. Southwest: Three Peoples in Geographical Change, 1600-1970. New York: Oxford University Press.

Meinig, D. W. 1986. The Shaping of America 1: A Geographical Perspective on 500 Years of History; Atlantic America, 1492-1800. New Haven: Yale University Press.

Meinig, D. W. 1993. The Shaping of America 2: A Geographical Perspective on 500 Years of History: Continental America, 1800-1867. New Haven: Yale University Press.

Meley, Patricia M. 1990. Adolescent Legend Trips a Teenage Cultural Response: A Study of Lore in Context. Mid-America Folklore 18: 1-26.

Middleton, Richard. 2007. O Brother, Let's Go Down Home: Loss, Nostalgia and the Blues. Popular Music 26: 57-60. [CrossRef]

Mikkelson, David. 2014. Country Rat, City Rat: Do Major Cities Harbor Roden Populations Equivalent to One Rat Per Person? Snopes.com: Rumor Has It, September 5. Available online: http:/ / www.snopes.com/critters / wild/rats.asp (accessed on 10 June 2016).

Mille, Richard De, ed. 1980. The Don Juan Papers: Further Castaneda Controversies. Santa Barbara: Ross-Erickson.

Mlotek, Chana, and Mark Slobin. 2007. Yiddish Folksongs from the Ruth Rubin Archive. Detroit: Wayne State University Press.

Moore, Jean Michael. 1986. Treasure State Treasure Tales: Stories about Lost Gold and Buried Treasure in Montana. Helena: Manx.

Morrison, Amanda Maria. 2008. Musical Trafficking: Urban Youth and the Narcocorrido-Hardcore Rap Nexus. Western Folklore 67: 379-96.

Mullen, Patrick B. 1972. Modern Legend and Rumor Theory. Journal of the Folklore Institute 9: 95-109.

Newell, William Wells. 1888a. Notes and Queries. Journal of American Folklore 1: 79-81.

Newell, William Wells. 1888b. On the Field and Work of a Journal of American Folklore. Journal of American Folklore 1: 3-7.

Newell, William Wells. 1889. [Introduction]. Journal of American Folklore 2: 1-2.

Newell, William Wells. 1992. Games and Songs of American Children. Baltimore: Clearfield. First published 1884.

Nickels, Cameron C. 1981. An Early Version of the 'Tar Baby' Story. Journal of American Folklore 94: 364-69.

Olsen, Steven L. 1996. Celebrating Cultural Identity: Pioneer Day in Nineteenth-Century Mormonism. Brigham Young University Studies 36: 159-77.

Orejuela, Fernando. 2014. Rap and Hip Hop Culture. New York: Oxford University Press.

Oring, Elliott. 2012. Dyadic Traditions. In Just Folklore: Analysis, Interpretation, Critique. Edited by Elliott Oring. Long Beach: Cantilever Press, pp. 80-90.

Oring, Elliott. 2014. Memetics and Folkloristics: The Applications. Western Folklore 73: 455-92.

Orr, David G., and Mark R. Ohno. 1981. The Material Culture of Protest: A Case Study in Contemporary Collecting. In Twentieth-century Popular Culture in Museums and Librarie. Edited by Fred E. H. Schroeder. Bowling Green: Bowling Green University Popular Press, pp. 37-54.

Osborn, Chase, and Stellanova Osborn. 1942. Schoolcraft_Longfellow-Hiawatha. Lancaster: Jaques Catell Press.

Oster, Harry. 1968. Negro Humor: John and Old Marster. Journal of the Folklore Institute 5: 42-57. [CrossRef]

Paredes, Américo. 1958. "With His Pistol in His Hand": A Border Ballad and Its Hero. Austin: University of Texas Press.

Paredes, Américo. 1976. A Texas-Mexican Cancionero: Folksongs of the Lower Border. Urbana: University of Illinois Press.

Paredes, Américo, and Richard Bauman, eds. 2000. Toward New Perspectives in Folklore. Bloomington: Trickster Press. First published 1972.

Parins, James W., and Daniel F. Littlefield, Jr., eds. 1995. Ke-ma-ha: The Omaha Stories of Francis La Flesche. Lincoln: University of Nebraska Press.

Peck, Andrew. 2015. Tall, Dark, and Loathsome: The Emergence of a Legend Cycle in the Digital Age. Journal of American Folklore 128: 333-48. [CrossRef]

Pentikainen, Juha. 1973. Belief, Memorate, and Legend. FolkloreForum 6: 217-41.

Perdue, Charles L., Jr. 1987. Outwitting the Devil: Jack Tales from Wise County, Virginia. Santa Fe: Ancient City Press. 
Perdue, Charles L., Jr. 2001. Is Old Jack Really Richard Chase? In Perspectives on the Jack Tales and Other North American Märchen. Edited by Carl Lindahl. Bloomington: Folklore Institute, Indiana University, pp. 111-38.

Pettit, Thomas. 1995. Contemporary Legend-The Debate Continues. Folklore 106: 96-100. [CrossRef]

Piersen, William D. 1971. An African Background for American Negro Folktales? Journal of American Folklore 84: 204-14. [CrossRef]

Philadelphia Chapter of the American Folklore Society. 1987. Hints for the Local Study of Folk-Lore in Philadelphia and Vicinity. In Folklife Studies from the Gilded Age. Edited by Simon J. Bronner. Ann Arbor: UMI Research Press, pp. 71-72. First published 1890.

Polenberg, Richard. 2015. Hear My Sad Story: The True Tales that Inspired "Stagolee", "John Henry", and Other Traditional American Folk Songs. Ithaca: Cornell University Press.

Porterfield, Nolan. 1996. Last Cavalier: The Life and Times of John A. Lomax, 1867-1948. Urbana: University of Illinois Press. Pound, Louise. 1922. American Ballads and Songs. New York: Charles Scribner's Sons.

Prizer, Tim. 2004. 'Shame Old Roads Can't Talk': Narrative, Experience, and Belief in the Framing of Legend-Trips as Performance. Contemporary Legend 7: 67-97.

Puglia, David J. 2015. Hon Culture Wars: Revering and Reviling the Vernacular in Baltimore and Beyond. Ph.D. dissertation, Pennsylvania State University, Harrisburg, PA, USA.

Radin, Paul. 1963. The Autobiography of a Winnebago Indian. New York: Dover. First published 1920.

Rings, Lana. 1994. Beyond Grammar and Vocabulary: German and American Differences in Routine Formulae and Small Talk. Die Unterrichtspraxis/Teaching German 27: 23-28. [CrossRef]

Roberts, John W. 1989. From Trickster to Badman: The Black Folk Hero in Slavery and Freedom. Philadelphia: University of Pennsylvania Press.

Roberts, Peter A. 1988. The Misinterpretations of Brer Anancy. Folklore 99: 98-101.

Roberts, Robin. 2006. New Orleans Mardi Gras and Gender in Three Krewes: Rex, the Truck Parades, and Muses. Western Folklore 65: 303-28.

Robinson, John A. 1981. Personal Narratives Reconsidered. Journal of American Folklore 94: 58-85. [CrossRef]

Roosevelt, Theodore. 1906. The Strenuous Life: Essays and Addresses. New York: Charles Scribner's Sons.

Roosevelt, Theodore. 1926a. The Ancient Irish Sagas. In Literary Essays by Theodore Roosevelt. New York: Charles Scribner's Sons, pp. 131-42.

Roosevelt, Theodore. 1926b. Nationalism in Literature and Art. In Literary Essays by Theodore Roosevelt. New York: Charles Scribner's Sons, pp. 325-36.

Rubin, Cynthia Elyce, and Moran Williams. 1990. Larger than Life: The American Tall-Tale Postcard, $1905-1915$. New York: Abbeville Press.

Rubin, Ruth. 1973. Voices of a People: The Story of Yiddish Folksong. New York: McGraw-Hill.

Sackman, Douglas Cazaux. 2010. Wild Men: Ishi and Kroeber in the Wilderness of Modern America. New York: Oxford University Press.

Sánchez, Martha I. Chew. 2006. Corridos in Migrant Memory. Albuquerque: University of New Mexico Press.

Saxe, Joel. 1997. The Giving of Yiddish Folksongs as a Cultural Resource. In Usable Pasts: Traditions and Group Expressions in North America. Edited by Tad Tuleja. Logan: Utah State University Press, pp. 120-36.

Scarborough, Dorothy. 1937. A Song Catcher in Southern Mountains: American Folk Songs of British Ancestry. New York: Columbia University Press.

Schoolcraft, Henry Rowe. 1986. Mental Character of the Aborigines. In Native American Folklore in Nineteenth-Century Periodicals. Edited by William M. Clements. Athens: Ohio University Press, pp. 52-60. First published 1859.

Schoolcraft, Henry Rowe. 1992. Algic Researches: Indian Tales and Legends, Volumes I EII. Baltimore: Clearfield, First published 1839.

Schramm, W. L. 1932. Hiawatha and its Predecessors. Philological Quarterly 11: 321-43.

Sebba-Elran, Tsafi. 2003. The Personal Narrative: From Memorate to Fabulate. Jerusalem Studies in Jewish Folklore, 69-98.

Sharp, Cecil J., and Olive D. Campbell. 1966. English Folk Songs from the Southern Appalachians. Edited by Maud. Karpeles. New York: Oxford University Press. First published 1932.

Sheviak, Margaret R., and Merrilee Anderson. 1969. American 'Fake' Folk Heroes. Elementary English 46: $273-78$. Shipley, Vivian. 1982. Jack Tales. Greenfield Center: Greenfield Review Press. 
Siporin, Steve. 2000. Tall Tales and Sales. In Worldviews and the American West: The Life of the Place Itself. Edited by Polly Stewart, Steve Siporin, C.W. Sullivan III and Suzi Jones. Logan: Utah State University Press, pp. 87-104. Skinner, Charles M. 1896. American Myths and Legends of Our Own Land. Philadelphia: J.B. Lippincott.

Skinner, Hubert M. 1893. Readings in Folk-Lore. New York: American Book Company.

Slotkin. 1973. Regeneration Through Violence: The Mythology of the American Frontier, 1600-1860. Middletown, CT: Wesleyan University Press.

Smith, Henry Nash. 1970. Virgin Land: The American West as Symbol and Myth. Cambridge: Harvard University Press. Spencer, Scott B. 2012. The Ballad Collectors of North America: How Gathering Folksongs Transformed Academic Thought and American Identity. Lanham: Scarecrow Press.

Spitzer, Nicholas R. 2011. Mardi Gras. In The New Encyclopedia of Southern Culture: Volume 16: Sports and Recreation. Edited by Harvey H. Jackson. Chapel Hill: University of North Carolina Press, pp. 147-54.

Spottswood, Richard K. 1990. Ethnic Music on Records: A Discography of Ethnic Recordings Produced in the United States, 1893 to 1942. Urbana: University of Illinois Press.

Stahl, Sandra K. D. 1977. The Personal Narrative as Folklore. Journal of the Folklore Institute 14: 9-30. [CrossRef]

Stanonis, Anthony J. 2006. Creating the Big Easy: New Orleans and the Emergence of Modern Tourism, 1918-1945. Athens: University of Georgia Press.

Stekert, Ellen J. 1986. The False Issue of Folklore vs. 'Fakelore': Was Paul Bunyan a Hoax? Journal of Forest History 30: 180-81. [CrossRef]

Sweterlitsch, Richard. 1996. Memorate. In American Folklore: An Encyclopedia. Edited by Jan Harold Brunvand. New York: Garland, pp. 990-92.

Sydow, C. W. von. 1948. Geography and Folk-Tale Oicotypes. In Selected Papers on Folklore. Copenhagen: Rosenkilde and Bagger, pp. 44-59.

Tangherlini, Timothy R. 1990. 'It Happened Not Too Far from Here ... ': A Survey of Legend Theory and Characterization. Western Folklore 49: 371-90. [CrossRef]

Taylor, Archer. 1944. The Tarbaby Once More. Journal of the American Oriental Society 64: 4-7. [CrossRef]

Thompson, Stith. 1922. The Indian Legend of Hiawatha. Publications of the Modern Language Association 37: $128-40$. [CrossRef]

Titon, Jeff Todd. 1980. The Life Story. Journal of American Folklore 93: 276-92. [CrossRef]

Tocqueville, Alexis de. 1966. Democracy in America. Edited by J. P. Mayer. Translated by George Lawrence. New York: Harper \& Row. First published 1835.

Toelken, Barre. 1986. The Folklore of Academe. In The Study of American Folklore: An Introduction, 3rd ed. Edited by Jan Harold Brunvand. New York: W. W. Norton, pp. 502-28.

Toelken, Barre. 1998. The Yellowman Tapes, 1966-1997. Journal of American Folklore 111: 381-91. [CrossRef]

Toelken, Barre. 2003. The Anguish of Snails: Native American Folklore in the West. Logan: Utah State University Press.

Tucker, Elizabeth. 1984. Levitation and Trance Sessions at Preadolescent Girls' Slumber Parties. In The Masks of Play. Edited by Brian Sutton-Smith and Diana Kelly-Byrne. New York: Leisure Press, pp. 125-33.

Tucker, Elizabeth. 1992. 'I Saw the Trees Had Souls: Personal Experience Narratives of Contemporary Witches. In Creativity and Tradition in Folklore. Edited by Simon J. Bronner. Logan: Utah State University Press, pp. 141-52.

Tucker, Elizabeth. 2005. Ghosts in Mirrors: Reflections of the Self. Journal of American Folklore 118: 186-203. [CrossRef]

Tucker, Elizabeth. 2007a. Haunted Halls: Ghostlore of American College Campuses. Jackson: University Press of Mississippi.

Tucker, Elizabeth. 2007b. Levitation Revisited. Children's Folklore Review 30: 47-60.

Tucker, Elizabeth. 2008. Campus Legends: A Handbook. Westport: Greenwood Press.

Tucker, Elizabeth. 2011. 'LMAO_That Wasn't Even Scary': Comments on Legend-Related Performances on YouTube. Contemporary Legend 3: 44-57.

Tucker, Elizabeth. 2012. From Oral Tradition to Cyberspace: Tapeworm Diet Rumors and Legends. In Folk Culture in the Digital Age. Edited by Trevor J. Blank. Logan: Utah State University Press, pp. 150-65.

Turner, Richard Brent. 2003. Mardi Gras Indians and Second Lines/Sequin Artists and Rara Bands: Street Festivals and Performances in New Orleans and Haiti. Journal of Haitian Studies 9: 124-56.

Uther, Hans-Jörg. 2004. The Types of International Folktales: A Classification and Bibliography. 3 vols. Helsinki: Suomalinen Tiedeakatemia.

Vance, Lee J. 1896-1897. The Study of Folk-Lore. Forum 22: 249-56. 
Vaux, Roberts, Joshua Francis Fisher, and Deborah Dependahl Waters. 1974. Philadelphia's Boswell: John Fanning Watson. Pennsylvania Magazine of History and Biography 98: 3-52.

Vernon, Paul. 1995. Ethnic and Vernacular Music, 1898-1960: A Resource and Guide to Recordings. Westport: Greenwood Press.

Wachs, Eleanor. 1988. Crime-Victim Stories: New York City's Urban Folklore. Bloomington: Indiana University Press. Wald, Elijah. 2001. Narcocorrido: A Journey into the Music of Drugs, Guns, and Guerillas. New York: Rayo.

Watson, John Fanning. 2009. Annals and Occurrences of New York City in the Olden Time. Carlisle: Applewood Books. First published 1846.

Watson, John Fanning. 1857. Annals of Philadelphia, and Pennsylvania. 3 vols. Philadelphia: Elijah Thomas.

Welsch, Roger L. 1976. Tall-Tale Postcards: A Pictorial History. South Brunswick: A.S. Barnes.

Wepman, Dennis, Ronald B. Newman, and Murray B. Binderman. 1976. The Life: The Lore and Folk Poetry of the Black Hustler. Philadelphia: University of Pennsylvania Press.

Wernitznig, Dagmar. 2003. Going Native or Going Naïve? White Shamanism and the Neo-Noble Savage. Lanham: University Press of America.

Whatley, Mariamne H., and Elissa R. Henken. 2000. Did You Hear about the Girl Who-? Contemporary Legends, Folklore, and Human Sexuality. New York: New York University Press.

Widdowson, J. D. A. 1977. If You Don't Be Good: Verbal Social Control in Newfoundland. St. Johns: Institute of Social and Economic Research, Memorial University of Newfoundland.

Wilgus, D. K. 1959. Anglo-American Folksong Scholarship since 1898. New Brunswick: Rutgers University Press.

Williams, Roger. 1643. A Key into the Language of America. London: Gregory Dexter.

Wilson, William A. 1991. Personal Narratives: The Family Novel. Western Folklore 50: 127-49. [CrossRef]

Workman, Mark E. 1992. Narratable and Unnarratable Lives. Western Folklore 51: 97-107. [CrossRef]

Wright, Richard A. 1989. The 'Friendly Student' Exercise. Teaching Sociology 17: 484-88. [CrossRef]

Yorgason, Ethan R. 2003. Transformation of the Mormon Culture Region. Urbana: University of Illinois Press.

Young, Kristi Bell. 2013. Now That I've Kissed the Ground You Walk On: A Look at Gender in Creative Date Invitation. In Latter-Day Lore: Mormon Folklore Studies. Edited by Eric A. Eliason and Tom Mould. Salt Lake City: University of Utah Press, pp. 114-22.

Zeitlin, Steven J., Amy Kotkin, and Holly Cutting Baker. 1982. A Celebration of American Family Folklore: Tales and Traditions from the Smithsonian Collection. New York: Pantheon.

Zelinsky, Wilbur. 1973. The Cultural Geography of the United States. Englewood Cliffs: Prentice-Hall.

(C) 2018 by the author. Licensee MDPI, Basel, Switzerland. This article is an open access article distributed under the terms and conditions of the Creative Commons Attribution (CC BY) license (http:/ / creativecommons.org/licenses/by/4.0/). 